\title{
AFTER THE BIG BANG? \\ OBSTACLES TO THE EMERGENCE OF THE RULE OF LAW IN POST-COMMUNIST SOCIETIES
}

\author{
Karla Hoff \\ Joseph E. Stiglitz \\ Working Paper 9282 \\ http://www.nber.org/papers/w9282 \\ NATIONAL BUREAU OF ECONOMIC RESEARCH \\ 1050 Massachusetts Avenue \\ Cambridge, MA 02138 \\ October 2002
}

\begin{abstract}
We are grateful to Avinash Dixit for valuable comments. We also thank Jeffry Frieden, Phil Keefer, Steve Knack, Branko Milanovic, Jean-Philippe Platteau, Arijit Sen, Anqing Shi, Ken Sokoloff, and seminar participants at the World Bank, the 2000 and 2001 NEUDC, the 2002 Annual Bank Conference on Development Economics in Oslo, the 2002 American Political Science Association Meetings, and meetings of the MacArthur Foundation Network on the Effects of Inequality on Economic Performance. The findings and interpretations expressed in this paper are those of the authors and do not necessarily represent the views of the World Bank or the National Bureau of Economic Research.
\end{abstract}

(C) 2002 by Karla Hoff and Joseph E. Stiglitz. All rights reserved. Short sections of text, not to exceed two paragraphs, may be quoted without explicit permission provided that full credit, including $(\mathrm{C}$ notice, is given to the source. 
After the Big Bang? Obstacles to the Emergence of the Rule of Law in Post-Communist Societies

Karla Hoff and Joseph E. Stiglitz

NBER Working Paper No. 9282

October 2002

JEL No. P26

\begin{abstract}
$\underline{\text { ABSTRACT }}$
When Russia launched mass privatization, it was widely believed that it would create a powerful constituency for the rule of law. That didn't happen. We present a dynamic equilibrium model of the political demand for the rule of law and show that beneficiaries of mass privatization may fail to demand the rule of law even if it is the Pareto efficient "rule of the game." The reason is that uncertainty about the legal regime can lead to asset stripping, and stripping can give agents an interest in prolonging the absence of the rule of law.
\end{abstract}

Karla Hoff

World Bank

MC 3-301

1818 H St.

Washington DC 20433

khoff@worldbank.org
Joseph E. Stiglitz

Uris Hall

Columbia University

Broadway and $116^{\text {th }}$ St.

New York City, NY 10027

and NBER

jes322@columbia.edu 
In recent years there has been a strong interest among economists in understanding the creation of the "rules of the game," understood in the broad sense of political economy, rather than merely the behaviors of agents within a given set of rules already in place. A remarkable opportunity to observe and try to influence the creation of the rules of the game occurred with the fall of communism in Eastern Europe and the former Soviet Union in the period 1989-91. At the outset, most observers agreed that were it politically feasible to establish quickly the rule of law to underpin a market economy as or before state enterprises were privatized, it would be desirable to do so. It was, however, argued that it was politically infeasible to do so. Advocates of rapid privatization, no matter how done, said "Not to worry." They argued that not only was an alternative reform dynamic feasible, but it would actually occur. Granting individuals the control of property would create a political constituency for the rule of law, where there is protection for private property rights. All over the post-communist world, Western donors promoted "Big Bang" privatization - the rapid transfer of state-owned enterprises to private economic agents (Przeworski et al. 1995, p. viii, at note 2). The paradigm that underlay this approach was articulated, for example, by Shleifer and Vishny (1998):

Privatization then offers an enormous political benefit for the creation of institutions supporting private property because it creates the very private owners who then begin lobbying the government...to create market-supporting institutions... [Such] institutions would follow private property rather than the other way around." (pp. 10-11)

But there was no theory to explain how this process of institutional evolution, including a legal framework for the protection of investors, would occur and, in fact, it has not yet occurred in Russia, in other former Soviet Union countries, in the Czech Republic, and elsewhere. A central reason for that, according to many scholars, is the 
weakness of the political demand for the rule of law. ${ }^{1}$ For example, Black et al. (2000) observe that in Russia, it was

hoped that broad private ownership would create a constituency for strengthening and enforcing [the new Civil and Commercial Codes]. That didn't happen. Instead, company managers and kleptocrats opposed efforts to strengthen or enforce the capital market laws. They didn't want a strong Securities Commission or tighter rules on selfdealing transactions. And what they didn't want, they didn't get. (p. 1753)

The contrast between what emerged and what the reformers hoped would emerge is brought out forcefully by Freeland (2000). She first quotes Anatoly Chubais, the principal architect of Russia's mass privatization, as describing Russia's businessmen: “"They steal and steal and steal. They are stealing absolutely everything..."” (p. 70). But she then quotes Chubais as supporting Coase's claim that all that is needed to make a market economy is private property, no matter how acquired: “"But let them steal...They will then become owners and decent administrators of this property"” (p. 70). However, at the time, Russia did not have a legal framework that protected property rights.

Freeland describes Chubais, like many Western scholars at that time, as supporting the "political Coase theorem," the notion that once control is turned over to private agents, they will ensure political reforms creating a rule of law: "Chubias hoped he could craft a program that would be impervious to the country's widespread corruption, one that might even take advantage of it. Businessmen's greed would make them privatization's most effective lobbyists; their corruption would stop once they became real owners" (p. 70). At the end, even most of the reformers became disillusioned: "[The reformers in Russia] thought that the central tenet of their faith, private property, was ultimately all that mattered - and watched helplessly as corruption, a weak state, and ineffective laws made

\footnotetext{
${ }^{1}$ On Russia, see Gray and Hendley (1997), Aslund and Dmitriev (1999), Stoner-Weiss (2001), and Kitschelt (2001). On Russia and other transition countries, see Black et al. (2000) and EBRD (2001, 2002).
} 
private ownership close to irrelevant" (p. 344).

This paper is part of a broader effort to shed light on the political demand for, and opposition to, the rule of law after the collapse of communism and the mass privatization of assets. ${ }^{2}$ Elsewhere, we have explored the constituency for the rule of law in an "oligopolistic" model, in which some agents have vast fortunes and influence over the media and political processes and direct their political energies to the creation of a legal order that gives them an advantage over others. To the extent that they succeed, the legal order that emerges will not be one that promotes economic efficiency. ${ }^{3}$ Here, however, we explore what we would interpret as a much more favorable set of conditions for the emergence of the rule of law. We present a model in which those with control rights over privatized assets are powerless individually to obtain property rights protection à la carte from the state, but can collectively bring about the rule of law simply by voting for it. If in this model mass privatization creates a constituency for the rule of law, it does not mean that one should view mass privatization as an effective strategy to establish the rule of law (for capitalists who are political insiders could still capture the state and establish a legal regime that privileged their own interests). But if privatization does not do that under the circumstances explored here, then the naïve view of institutional change that

\footnotetext{
${ }^{2}$ We briefly summarize some analytical contributions on the obstacles to the rule of law in the postcommunist states. (1) Johnson, Kaufmann, and Shleifer (1997), Roland and Verdier (1999), and Glaeser, Johnson, and Shleifer (2001) focus on constraints on supply: Government may be unable to collect taxes to finance a market-oriented legal system, or judicial enforcement of legal rules may be ineffective. (2) Dewatripont and Roland $(1992,1995)$ and Hellman (1998) focus on the problem of sustaining the demand for reform over time: voters who suffer short-term losses may turn against reform, or the early winners from partial reform may block continuation of reforms in order to earn rents. In contrast, the absence of a political demand for the rule of law even when that legal regime would advance the interests of the majority of decision-makers is the central phenomenon addressed in this paper.

${ }^{3}$ Hoff and Stiglitz (2002). Engerman and Sokoloff (2002) present many historical examples where a small wealthy class was able to capture the state, and found it in its self-interest to put in place a legal regime that limited participation in markets and development by a broad section of the population.
} 
was adopted to justify quick privatization should be viewed with considerable skepticism. This paper shows that the beneficiaries of privatization may fail to support the rule of law even if it is the Pareto efficient "rule of the game."

To make this point in a simple way, we consider a society in which the possible legal structures vary only along the dimension of the security of property rights. The two possible legal regimes in our model capture the ends of the spectrum. By the rule of law we mean well-defined and enforced property rights, broad access to those rights, and predictable rules for resolving property rights disputes. By no rule of law we mean a legal regime that does not protect investors' returns from arbitrary confiscation, does not protect minority shareholders' rights from tunneling, and does not enforce contract rights.

Our approach—like most of the popular discussions—oversimplifies the issue of rule of law and property rights in several ways. Simplistic discussions treat the state as "owning" and "controlling" assets before privatization and treat privatization as the transfer of title to a private economic agent, who then has complete control. The rule of a law is sometimes defined by depicting its opposite: a state of anarchy. Both concepts are more subtle. For instance, in Russia the law has been used by some powerful groups to appropriate assets away from others through an abuse of bankruptcy processes. In some cases, the law has been used to create entry barriers to maintain monopoly positions. Our use of the term "rule of law" focuses on the enforcement of property rights in a reasonably neutral and predictable way: ${ }^{4}$ under the "rule of law," the ability of the local, regional, and national authorities to take arbitrary actions is circumscribed. But in Russia, privatization may have actually expanded the discretion of the subnational

\footnotetext{
${ }^{4}$ In a sense, the mathematics of the equations in our model define what we mean by the "rule of law"legal structures that change relative net pay-offs in the way assumed.
} 
authorities. Under any legal regime, minority shareholders have "ownership" rights in the sense of clear title, but typically few control rights. In Russia, the absence of a rule of law meant that reportedly even the ownership rights were of dubious value. Overnight, a shareholder could see his interests diluted and his assets tunneled away. More remarkably, in many of the post-communist countries, even majority shareholders encountered such problems (Black et al. 2000).

We are leaving out other conceivable solutions to the problem of providing incentives for wealth creation, such as individuals' allocation of resources to defend the property they produce, and non-governmental (voluntary) enforcement of property rights and contracts. Needless to say, such arrangements by and large did not work in Russia, and there are few instances where they have been effective on the scale of a nation-state (Frye 2000 provides a set of case studies for Russia).

In our model, agents with control rights over privatized property are concerned with the wealth they can obtain from these rights, and have two alternative strategies: building value and stripping assets. Building value under the rule of law yields higher benefits to a majority of the agents than any feasible alternative. But uncertainty about whether the rule of law will be established may lead individuals to choose certain economic strategies — stripping assets, including converting corporate and social assets to private use - that give them an interest in prolonging the state of no rule of law. As a result, a small constituency for the rule of law and a low probability of transition to the rule of law can be an equilibrium.

In our analysis, we try to parse out the role of various "market failures." We show that how agents vote influences other agents' actions (a spillover effect), and how 
each agent acts influences his political position (an intertemporal incentive effect). Each individual, in attempting to exercise influence on the choice of the environment, focuses on the impact on himself, not on others.

The political environment, in that sense, is a public good; and in the no-rule-oflaw state, the assets themselves can be viewed as having attributes of a common resource. What an individual takes out for himself from this common resource adversely affect what is available for others. Knowledge that property rights will be well established in the future may exacerbate the pillage today; and by the same token, the externalities that are mediated through the political environment can lead agents to take actions that give them an interest in prolonging the no-rule-of law state. ${ }^{5}$

Many of the factors that in our model reduce the constituency for the rule of law are present in Russia: lack of experience of a market economy before communism, an historical legacy of corruption, a corrupt privatization, abundant natural resources, open capital markets, and a hyperinflation in 1992-93 that by destroying private savings aggravated the consequences of imperfect capital markets. Thus, the model helps explain why what happened in Russia actually happened. The framework used for the analysis is quite general and so it also makes predictions about policies - macroeconomic and capital market policies - that will help move a society towards the rule of law.

It should not be surprising that inefficient "rules of the game" can emerge as a Nash equilibrium. It is only under highly restricted conditions that Nash equilibria are

\footnotetext{
${ }^{5}$ This was particularly the case in Russia so long as there were state assets to be distributed; all of those who thought that they might have a chance at obtaining these state assets on favorable terms wished to delay the rule of law regime. To put it graphically, they wanted one more "bite of the apple." Our analysis assumes everyone is "small," but in practice, as we note below, the second phase of privatization in Russia (the "loans for shares" program) created oligarchs who, possibly singly, but certainly in concert, had the power to delay the rule of law. Freeland (ch. 12) argues that in 1997 at least one of them felt he had not gotten his share of the state assets, and threatened to-and did block-reforms in a valiant attempt to do so.
} 
efficient (Greenwald and Stiglitz 1986). The initial set of institutions is not one of complete markets, and the question we address is really whether decentralized choices by atomistic agents will lead to an efficient outcome. In this respect, this paper is related to work by de Meza and Gould (1992) and Greif (1994) on the Nash equilibrium choice of enforcement of property rights.

Institutional change is in essence a dynamic phenomenon - its costs and benefits are borne in the future. Nevertheless, for expositional purposes, we begin in Sections 2 and 3 by presenting a static model in the standard framework of a coordination game. Section 4 introduces the complication that agents are intertemporal decision makers. This is followed by a discussion of the role of the key assumptions of the model. To place the question addressed in the model in historical context, the next section provides a capsule history of the privatization process in Russia.

\section{Overview of Privatization in Russia}

In December 1991, the USSR was dissolved. In the next year, Russia implemented Big Bang reforms. In Russia, these measures deregulated most prices and launched a mass privatization program, which distributed equity to managers and workers and sold shares at public auctions. By July 1994, when the mass privatization program was completed, 14,000 medium and large state enterprises (70 percent of Russian industry) had been transformed into joint-stock companies. On average, firm insiders accounted for 70 percent of shares held in privatized enterprises . Because worker and outside ownership was so dispersed, management exercised effective control in most employee-owned firms (Frydman et al. 1996, and Blasi et al. 1997).

In 1995-97, a second wave of privatizations - this time of many of the most 
valuable enterprises of the metals, oil, and utilities sectors - occurred through a program known as 'loans for shares.' While the first privatization program was plagued with inequities - e.g. the nomenklatura often wound up with a disproportionate amount of the shares by withholding wage payments until workers had no choice but to sell shares (Black et al. 2000; Freeland 2000, p. 93) —'loans for shares' particularly was viewed as the use of state power for special interests (Lieberman and Veimetra 1996). The program gave rise to the term oligarchs to refer to the small group of bankers and industrialists who received billions of state assets in exchange for help in reelecting President Yeltsin.

Mass privatization was initiated before institutions to support the rule of law were in place. Such institutions are imperfect in all societies, but between Russia and most other developed, capitalist societies there was a qualitative difference. There were few rules for corporate governance, and no rules to make management teams contestable. The president could rule by decree. In 1995-96, Russia adopted laws to protect shareholders' rights, but political opposition (free elections have been held regularly since 1993) made enforcement of these rules very weak.

The transfer of state property to private agents was accompanied by the stripping of Russia's assets. Capital flight from Russia averaged, depending on the measure used, more than $\$ 20$ billion or $\$ 15$ billion per year during 1995-2001, or 5\% of GDP (Loungani and Mauro, 2001; Reuters, Feb. 20, 2002). Over the period for which data are available (1995-99), private net fixed capital formation was negative; Russia, a relatively capitalpoor country, was a net exporter of capital to the West (Buiter, 2000).

Systematic evidence of the insecurity of property rights in Russia and 21 other transition economies comes from a 1999 EBRD/World Bank survey of firms. In 
response to the survey question, "I am confident that the legal system will uphold my contract and property rights in business disputes," a staggering 75 percent of firms in Russia, Kyrgyzstan, Moldova, and the Ukraine stated that they disagreed. Figure 1 is a scatter plot of data on property rights insecurity and growth for all countries for which such data are available. ${ }^{6}$ The horizontal axis plots the fraction of firms in the EBRD/World Bank survey that report that they do not trust the legal system to uphold their property and contract rights. The vertical axis plots the percentage change in GDP between 1989 and 2000. In the six economies where property rights are most insecure, GDP has sharply contracted - by official statistics, the contraction is more than 30 percent. ${ }^{7}$ Johnson et al. (2002) find in their survey of firms in post-communist countries that weak property rights discourage firms from reinvesting their profits, and so are a causal factor in poor economic outcomes.

\section{A static model of the demand for the rule of law}

To give intuition, we start with a model in the standard framework of a coordination game.

Agents. Suppose that time consists of two periods. Each agent exercises some control rights over enterprises in the first period, and chooses between two actions: ${ }^{8}$

Build value: Make an irreversible investment to increase the enterprise's value.

Strip assets: Strip the assets of the enterprise, whisk capital to a safe place,

\footnotetext{
${ }^{6}$ In each country except Belarus, the private sector emerged from a very small share of the economy in 1989 to the dominant share by 2000 (EBRD 2001).

${ }^{7}$ Official statistics are an imperfect measure because the unofficial economy as a proportion of the total economy varies across states. Given available data on poverty rates, electricity use, and mortality, the qualitative patterns appear accurate (see, e.g., Johnson, Kaufmann, and Shleifer 1997).

${ }^{8}$ For simplicity, we treat these two strategies as mutually exclusive. For an enterprise where claims to income are concentrated in a sole shareholder, there would never be a reason to do both simultaneously. For a firm with multiple shareholders, the controlling shareholder might want to pursue both the valuecreating and the self-dealing strategies, but that would not be sustainable, as investors would ultimately refuse to do business with a firm that defrauds them.
} 
tunnel value out, and let the capital stock wear out.

The economy consists of a continuum of agents normalized to 1 and indexed by $\theta$. Those with a higher value of $\theta$ strip better. (The payoff from stripping an enterprise is larger, the more liquid its assets, the larger its debt, and the greater the equity of minority shareholders.) $\theta$ has a continuous, differentiable distribution over $\left[\theta_{\min }, \theta_{\max }\right]$ given by $H(\theta)$, with a density function $h($.$) associated with it. { }^{9}$

Political environment. The initial state is one without the rule of law. Agents who build value demand reform - the rule of law—because it is the only legal regime that enforces property rights. Asset-strippers, who follow a strategy of "take the money and run" and can illegitimately profit from their control rights, do not. The economic strategy of an agent thus determines his political position..$^{10}$ Let $x$ denote the fraction of agents who do not support the rule of law. We assume that the probability $\pi$ of the establishment of the rule of law depends on the size of the constituency for it (1-x) as well as many other factors (e.g., freedom of the press, the structure of political parties, and random shocks). We capture this assumption as:

$$
\pi=\pi(x), \quad \pi^{\prime}(.) \leq 0, \quad 0=\pi(1)<\pi(0)=1 .
$$

Payoffs. Technology is constant returns to scale. One unit of an asset yields a pay-out $f$ in the first period. An agent of type $\theta$ who strips realizes an additional value $\theta$ per unit asset, and so has a total return per unit asset of ${ }^{11}$

\footnotetext{
${ }^{9}$ We simplify by focusing on stripping ability as the only source of differences across agents in the relative returns to building value and stripping assets. Nothing depends on this simplifying assumption.

${ }^{10}$ This is not the case in the dynamic extension of this model below.

${ }^{11}$ The payoff to stripping is independent of the legal regime; thus, for strippers it does not matter which legal regime is in place. We generalize this later (see equation (4)).
} 


$$
s(\theta)=f+\theta
$$

An agent who builds value invests an amount $I^{j}$ and increases the asset to an amount $g .{ }^{12}$ Thus he obtains $V^{j}$ in the second period, which depends on the legal regime, indexed by $j$, where $j$ is rule of law $(L)$ or no rule of law $(N)$ :

$$
V^{j}=f+g-I^{j}
$$

We assume that $I^{L}<I^{N}$, which captures the idea that in order to build value, an agent must interact with others in the economy. He benefits from the rule of law because it enforces property rights and contracts, and thereby expands his access to both domestic and foreign markets for inputs and credit; without the rule of law, he risks even being able to capture the return on his investment. ${ }^{13}$

The model makes an important simplification that leads to an underestimate of the value of the rule of law: it abstracts from externalities that affect $f$ and $g$. If a large fraction of the economy is engaged in asset stripping, then (as in Russia in the 1990s) overall production will suffer, and $f$ and, most importantly, $g$ will be depressed. ${ }^{14}$

Figure 2 summarizes the payoff structure for an agent of type $\theta$. We assume that the majority of agents are strictly better off building value under the rule of law than stripping assets: $g-I^{L}>\theta_{\text {median }}$.

\footnotetext{
${ }^{12}$ In the dynamic version presented below, $g$ represents the proportionate increase.

${ }^{13}$ For simplicity, we have modeled the technology as requiring a given level of investment, so that in the absence of the rule of law, higher levels of investment are required; alternatively, we could have modeled the rule of law as entailing a reduced return from the same level of investment. Again, nothing depends on the simplification chosen.

${ }^{14}$ In particular, the return to asset stripping will be increased relative to that of investing. There are other channels besides the impact on aggregate demand. With lower levels of production, the demand for nontraded intermediate goods is reduced, and this has adverse effects on aggregate supply. If many people are engaged in corruption, the relative returns to being honest may fall. The importance of these kinds of social interactions has been emphasized in Murphy, Shleifer, and Vishny (1993) and in Hoff and Stiglitz (2001), which contains references to a vast literature.
} 
Given $x$, the threshold below which agents build value and demand the rule of law, and above which they do not, is a type $\theta^{*}$ such that

$$
\theta^{*}(x)=g-\pi(x) I^{L}-[1-\pi(x)] I^{N} \quad \text { Switch line }
$$

and so a population fraction 1-H( $\left.\theta^{*}\right)$ strips and supports the status quo, "no rule of law."

Equilibrium. Equilibrium is defined in terms of the constituency for the status $q u o$ (no rule of law). An equilibrium is a value of $x$ such that

$$
x=1-H\left(\theta^{*}(x)\right) .
$$

We will call the function $x(\theta)=1-H(\theta)$ the stripping ability curve. Figure 3 shows a possible shape that the switch line and stripping ability curve may take. An interior equilibrium occurs as any pair $\left\{\theta^{*}, x\right\}$ where the two curves intersect.

Proposition 1. An equilibrium always exists. If $0<x^{*}<1$ is an equilibrium where

$$
-h\left(\theta^{*}\left(x^{*}\right)\right)\left\{\pi^{\prime}\left(x^{*}\right)\left[V^{L}-V^{N}\right]\right\} \geq 1,
$$

then there are also at least two other equilibria, one with a greater and one with a lower probability of the establishment of the rule of law. On the other hand, if for all $x$, $-h\left(\theta^{*}\left(x^{*}\right)\right) \pi^{\prime}\left(x^{*}\right)\left[V^{L}-V^{N}\right]<1$, then the equilibrium is unique.

Proof. $\phi(x)=1-H\left(\theta^{*}(x)\right)-x$ satisfies $\phi(0) \geq 0, \phi\left(x^{*}\right)=0$, and $\phi(1) \leq 0$ and is continuous. If (3) holds, $\phi^{\prime}\left(x^{*}\right)>0$.

The first factor in (3) is the density of agents who are indifferent between the two actions. The second factor is the marginal impact of $x$ on the return to building value; it captures the intensity of the externality mediated through the political system. Prop. 1 states that if the externality is sufficiently large, then multiple equilibria will exist.

This can be seen in another way. If (3) holds, the switch line (with slope $\pi^{\prime}\left[V^{L}\right.$ - 
$\left.V^{N}\right]$ ) cuts the stripping ability curve (with slope $1 / h(\theta)$ ) from above, or coincides with it. The equilibrium is unstable because a perturbation that increases $x$ lowers the switch point by at least as much as it lowers the return of the marginal asset-stripper, which induces movement away from the equilibrium. Figure 3 illustrates a case where there are three equilibria, of which $x^{*}$ and $x * * *$ are stable. Since payoffs are (weakly) decreasing in $x,{ }^{15}$ the equilibria are Pareto-ranked and reflect a coordination problem.

Example. Suppose $\pi(x)=(1-x)^{2}, \theta$ is uniformly distributed on [0,1], and returns to building value are $g-I^{L}=1$ and $g-I^{N}=1 / 4$. Then equation (2) becomes $x=1$ $\theta^{*}(x)=3 / 4-3 / 4(1-x)^{2}$. Equilibria are $x^{*}=0$ and $x * *=2 / 3$; see Figure 4. This simple example illustrates several points. Even if building value under the rule of law dominates stripping assets for every agent, a weak constituency for the rule of law may be the unique stable equilibrium. The switch line is steeper than the stripping ability curve at $x$ $=0$. Thus (3) holds and the efficient equilibrium, where the transition to the rule of law occurs with certainty in the next period, is unstable. By similar reasoning, the inefficient equilibrium, where the transition probability is $1 / 9$, is stable.

The model sheds light on the debate about rapid privatization. The optimistic view was that privatization would create a class of individuals who stood to gain enormously by building up the value of their firms and who would thus demand the rule of law. Observers of the Russian scene quipped, Why steal Gazprom [a Russian energy

\footnotetext{
${ }^{15}$ The payoff to type $\theta$ when a fraction $x$ of the agents do not support the rule of law is:

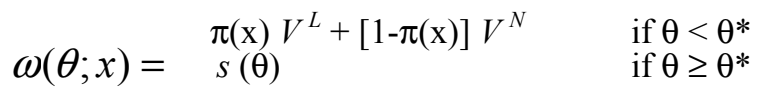

For $\theta<\theta^{*}, \partial \omega / \partial x=\pi^{\prime}\left[V^{L}-V^{N}\right]<0$. For $\theta \geq \theta^{*}$, and $\partial \omega / \partial x=d s(\theta) / d x=0$.
} 
firm and the world's largest producer of natural gas] if you can make billions from it? ${ }^{16}$

One answer has to do with the credibility of property rights. If an individual's property rights to Gazprom are not (expected to be) enforced in the future, then he cannot make billions (by normal business investments). This point is strengthened if we recognize that control rights can extend well beyond ownership rights. Those who have an advantage in asset-stripping relative to wealth creation may also have an advantage in converting corporate and social assets to private use, and accordingly will not support the rule of law even when they themselves have assets to protect. As the oligarch Boris Berezovksy might have said, Why create when you can steal? ${ }^{17}$ Our analysis suggests that there is some truth in both views-building value may be rational and stripping assets may be rational — but that unfortunately there can exist an equilibrium in which the latter prediction on this is the one that seems to have emerged.

\section{Comparative statics}

We can incorporate in our simple static framework a wide variety of factors that scholars have argued influence the political demand for the rule of law in post-communist societies. All the qualitative results of this section will hold as well in the dynamic version of the model presented later.

Figures $5 \mathrm{~A}$ and $\mathrm{B}$ provide the basic insights. Any change in the parameters of the model that shifts up the stripping ability curve leads to an increase in $x$ at a stable

\footnotetext{
${ }^{16}$ A variant of this quip is in Frydman, Murphy, and Rapaczynski (1998, p. 54).

${ }^{17}$ Boris Berezovsky has been described as a master at devising schemes that "soaked cash out of the big companies he dealt with, leaving them effectively bankrupt" (Klebnikov, 2000, p. 4). One of his widely announced plans was to produce a new Russian car in a joint venture with Avtovaz and General Motors. Reportedly he used the proceeds of a public securities sale not to build the factory but "to bootstrap himself and [an Avtovaz manager] into private ownership of [Avtovaz, an 'industrial crown jewel of Russia']" (Hoffman, 2002, pp. 217, 226). In 1994, "GM backed out of the...project, alarmed by gangsterism and corruption at Avtovaz (Klebnikov, p. 141). The factory was never built.
} 
equilibrium - and accordingly to a decrease in the "value" of the equilibrium. A large enough upward shift can lead to the elimination of the "good" equilibrium. We will describe such a situation loosely as "making a wealth-creating equilibrium less likely." By the same token, any change in parameters that results in a downward shift in the switch line has similar effects to an upward shift in the stripping ability curve.

We now describe more precisely what kinds of shifts lead to these results. We define three parameters to capture exogenous factors that change, respectively, the distribution of stripping abilities (the parameter $\varepsilon$ ), the net return to building value $(\alpha)$, and the probability of the establishment of the rule of law $(\gamma)$ :

$$
\begin{aligned}
& H=H(\theta ; \varepsilon) \text { with } H_{\varepsilon}<0 \\
& I^{j}=I^{j}(\alpha) \text { with } d I^{j} / d \alpha<0 \\
& \pi=\pi(x ; \gamma) \text { with } \pi_{\gamma}>0 \text { for } x \in(0,1) \text { and otherwise } \pi_{\gamma}=0 .
\end{aligned}
$$

An increase in $\varepsilon$ shifts down the distribution of abilities to strip and so shifts $u p$ the stripping ability curve. An increase in $\alpha$ or $\gamma$ shifts up the switch line. ${ }^{18}$

PROPOSITION 2. (i) Evaluated in the neighborhood of a stable interior equilibrium,

$$
d x / d \varepsilon>0, \quad d x / d \alpha<0, \quad \text { and } d x / d \gamma<0 .
$$

(ii) There is a social multiplier. Parameter changes have both a direct effect on the demand for the rule of law, when all agents treat the actions of other agents as fixed, and an indirect effect of the same sign, as agents respond to the change in actions by others.

PRoof. See the appendix.

We consider, in turn, three applications: initial conditions, "civic virtue," and policy.

\footnotetext{
${ }^{18}$ Some factors could have effects of opposite sign at different points along the stripping ability curve or the switch line. Our results do not depend on the uniformity of the effect of a given factor on one or the other of these curves; what matters is only the effect evaluated at the initial equilibrium point.
} 
Initial conditions. What people see has happened in the past affects what they believe will happen in the future. Russia had the experience of 74 years of rule by the Communist Party, which was bound by no laws. A consequence of a prolonged experience of communism was the absence of civil society institutions (churches, the press, political clubs) with countervailing power to hold the state to account (Gellner 1994). (In contrast, Poland had powerful social networks, including the Catholic Church and the Solidarity trade union.) During the long period of Soviet rule, a parallel, informal structure grew up alongside the official Party structure, in which people exchanged favors and engaged in illegal trades, often at the expense of the State. This structure survived the collapse of the Soviet rule. As a Russian businessman explained,

All large-scale [Russian criminal] operations -financial swindles, non-paid loans, investment projects, in which millions vanished in unknown directions - are mostly based on former connections (quoted in Ledeneva, 1998, p. 211).

The parallel structure that was a legacy from the Soviet period also made it easy for mafias to infiltrate the Russian government (Anderson 1995, Platteau 2000). A corrupt privatization process reinforced pessimistic beliefs about the way society works. Each of these "initial conditions" represents a shift down in $\pi(. ; \gamma)$ or in $H(. ; \varepsilon)$. Both shifts reduce the constituency for the rule of law; see Figure 5.

Consider next the role of factor endowments. All assets can be viewed as a depletable resource. But whereas much of the value of the industrial base is linked to future access to markets, which cannot be stripped, many natural resources are by comparison easy to strip. This suggests the hypothesis that relative natural resource abundance (relative to industrial assets) represents a shift down in $H(. ; \varepsilon)$, reducing the 
constituency for the rule of law; see Figure 5A.

We present Table 1 as motivation for this hypothesis rather than as supporting results. ${ }^{19}$ We report two measures of natural resource abundance-exports of fuel and minerals as a fraction of total exports and as a fraction of GDP — and three outcome measures - growth, the 1999 EBRD/World Bank measure of property rights insecurity discussed in Section 1, and the Wall Street Journal index of the rule of law. ${ }^{20}$ In countries with low natural resource exports ( $<10$ percent of total exports), “only" 40 percent of firms disagree with the statement that "the legal system will uphold my contract and property rights"; and the Wall Street Journal index is 7.5 out of a possible score of 10 . In countries with high natural resource exports $(>20$ percent of total exports), nearly 70 percent of firms disagree with the statement that their property rights will be upheld; and the Wall Street Journal index is 4.2.

Our model suggests an explanation for this pattern, which is related to the "now almost conventional wisdom that [natural] resources are a 'curse' for currently developing countries" (see, for example, Ross 1999 and Robinson, Torvik, and Verdier 2002). But whereas existing theories focus on the so-called rentier states (which use their control over natural resources to maintain their power and wealth without adopting a legal regime that is broadly beneficial) or on the dissipation of resources through

\footnotetext{
${ }^{19}$ The sample of 14 countries for which data on natural resource abundance are available is too small and heterogeneous to draw reliable conclusions. Even with a larger sample, a cross-section study could not test this hypothesis because it could not distinguish the direction of causation. Natural resource abundance, by influencing the relative returns to stripping and building assets and, hence, the constituency for the rule of law, influences the legal regime. But the absence of the rule of law, by depressing "contract-intensive" sectors in manufacturing relative to those in natural resource sectors (Blanchard and Kremer 1997) increases the measures of natural resource abundance. Fuel and mineral exports as a fraction of total exports in Russia rose from 53.2 to 60.6 percent between 1996 and 2000, as exports in manufacturing fell and natural resource exports rose (World Bank, Statistical Information and Management Analysis).

${ }^{20}$ The Wall Street Journal's panel of investment professionals rates the transition economies according to the "rule of law" on a scale of 0 (the worst) to 10 (the best).
} 
competitive rent-seeking and patronage, we emphasize a different mechanism: a greater ratio of natural resources to industrial assets in an economy with weak property rights increases the relative returns to stripping (relative to building value), which, in turn, decreases the political constituency for the rule of law.

Civic virtue. With a slight modification of the model, we can consider the effect of the presence in the population of agents who always support the rule of law, irrespective of their private interests. ${ }^{21}$ We can show that their presence will increase the incentive of self-interested agents to support the rule of law (a social multiplier).

Suppose society is composed of two types of people: A proportion $p$ have "civic virtue" and always support the rule of law. A proportion 1-p are "opportunists" who are like the agents in our model, with $\theta$ distributed according to $[1-p] H(\theta)$. Let $x^{*}$ denote the equilibrium if $p=0$, and $x^{\text {mixed }}$ the equilibrium if $p>0$. Then

PRoposition $3 \quad x^{\text {mixed }}<[1-p] x^{*}$.

PRoor. See the appendix.

Proposition 3 shows that the existence of individuals with civic virtue can play a disproportionate role in bringing about the "good" equilibrium. Historically, the framers of the US Constitution not only recognized that idea, but incorporated it into their own behavior: even when not in public service, they went to extraordinary lengths to protect their reputations. ${ }^{22}$ The converse is that the loss of civic virtue-as occurred in Russia when corrupt managers or criminal figures obtained control rights through official

\footnotetext{
${ }^{21}$ This modification is related to Haltiwanger and Waldman (1991).

${ }^{22}$ A reputation for civic virtue is a means "to keep myself in a situation best calculated to render service," wrote Alexander Hamilton (cited in Wood, 1991, p. 265). "Many of [George Washington's] actions after 1783 can be understood only in terms of this deep concern for his reputation as a virtuous leader....[the] ratification [of the US Constitution] was a kind of ratification of himself" (Wood, pp. 207-9).
} 
privatizations - may have had a disproportionate effect in bringing about the "bad" equilibrium.

Our framework can also be applied to illustrate a multiplier that may arise from coalitional politics. Suppose that agents are affected by a vector of policies—not just the legal regime but also other policies, such as social insurance. Then agents that care more about social insurance than the legal regime might enter into a political coalition with those who support the rule of law. By making a commitment to the rule of law, they will play a role analogous to that of the "virtuous" agents described above.

Policy. Demand for, and opposition to, the rule of law cannot be separated from macroeconomic policy, from other rules such as financial market liberalization, and, most clearly, from the nature of the privatization process. Monetary policy has several effects: Policy that leads to higher real interest rates lowers the discount factor and increases the cost of capital. Policy that makes credit unavailable stacks the balance even more against building value. ${ }^{23}$ These effects raise $I^{j}(\alpha)$ and make the establishment of the rule of law less likely, in a manner similar to that depicted in Figure 5B.

Monetary policy also affects the state of the economy. By reducing the risk of inflation, and especially the threat of hyperinflation, a restrictive monetary policy is an important tool for enhancing confidence in economic stability and thus raising the return to building value. But it is possible that the negative effects described above outweigh this positive effect. The outcome of restrictive monetary policy could be even worse than the model implies because our static model abstracts from the fact that as asset stripping goes on, the aggregate supply function shifts back. The shift back in potential GDP itself

\footnotetext{
${ }^{23}$ There are some complicated intertemporal arguments whereby some economists have suggested that high interest rates today allow lower interest rates in the future, in which case, were that believed, the impact on the return to building value would be different.
} 
creates inflationary pressure and obviates the possibility of lower interest rates, which were part of the healthy dynamics that are traditionally predicted. ${ }^{24}$

Consider next the effect of capital market liberalization. In the absence of the rule of law, people have a strong incentive to take measures to protect their property from predation by the state and mafias. Capital market liberalization introduces a new "technology" for asset-strippers to protect themselves from predation, one not available to those who undertake domestic wealth creation: If capital can be hidden abroad, then it cannot be seized. This effect may strongly shift the balance of incentives in favor of stripping, shifting down $H(. ; \varepsilon)$ and making the rule of law less likely; see Figure 5A.

Finally, consider the effects of institutional design. We have modeled only those individuals who control privatized firms (of which there were over 14,000 in Russia by 1994) because the question that motivates our analysis concerns their political demands. We have not addressed the political influence of others in society. Such influence is increased by institutional designs that provide for freedom of the press, separation of powers, and broad access to information about government and publicly owned firms; formally, these features lower $\pi^{\prime}(x ; \gamma)$.

\section{A dynamic extension}

The preceding sections presented a "chicken and egg" model where the uncertainty of the legal environment could lead individuals to adopt certain economic strategies and, given those economic strategies, they would not support the rule of law. But do the

\footnotetext{
24 After Russia's GDP had fallen by 40 percent over the period 1990-96, it was widely believed that any loosening of monetary policy would lead to inflation, which might have been true but could be interpreted to mean that 72 percent of productive capacity had been destroyed. We abstract from contracting problems (which also contributed to the fall in output) and use a Cobb-Douglas production function to obtain this estimate. If the capital share is 0.4 , then the capital stock as a fraction of its initial level implied by a 40 percent fall in GDP is $(0.6)^{10 / 4}=0.28$.
} 
implications of that model extend to a dynamic framework? One might think not. After all, forward-looking agents may simultaneously strip (for the sake of current gains) and support the rule of law (for the sake of future gains). The support base for "no rule of law" and the agents who strip are not necessarily the same. In order to analyze this problem, in this section we extend the model to a dynamic framework. In our extension, two variables link an agent's current decisions with his future opportunities. First, a current decision to strip assets reduces the stake that an agent has in the future legal regime. Second, such a decision reduces his relative return from the rule of law (relative to no-rule-of-law) because the establishment of the rule of law at the end of a given period constrains his ability to strip. Given these links between present and future, we show that the qualitative results of the static model carry over to a dynamic framework.

\section{A. Assumptions}

Timing. Agents live forever, discounting the future by $\delta$. In the initial period, the economy has no rule of law. In each period the timing is:

Stage 1. Agents choose an action — to build value or strip assets — and a political position - for or against the rule of law.

Stage 2. A state $N$ or $L$ is realized, and payoffs are received.

Transition probabilities. The probability of transition to the rule of law depends, as before, on the constituency for reform. We shall not investigate all possible equilibria, but instead explore a subset of possible equilibria where, as long as the no-rule-of-law state prevails, the constituency for reform remains the same over time:

$1-x_{t}=1-x_{t+1}=1-x_{t+2}=\ldots$. There are other dynamics where the constituency may jump from one period to the next, which we do not explore.

After a society attains the rule of law, we assume that it continues in that state 
forever. (Similar results for our model would hold if there were a small probability of reversion to the state of no rule of law.)

Technology and payoffs. One unit of an asset produces a flow of value $f$ each period, forever. By building value, an agent reduces the current flow from $f$ to $b^{j}=f-I^{j}$, with $I^{L}<I^{N}$, and increases the asset to a proportion $\widetilde{g}>1$ of its former size. We assume $1>\delta \widetilde{g} \equiv g$, so that asset values are finite.

Alternatively, by stripping assets, an agent increases the current flow at the cost of reducing the asset to a proportion $\widetilde{z}<1$ of its former size. Let $z$ denote $\delta \widetilde{z}$. An agent of type $\theta$ can only strip so much, and the rule of law further constrains his ability to strip:

$$
s^{N}(\theta)=f+\theta, \quad s^{L}(\theta)=f+\theta[1-\lambda] \quad \text { with } 0<\lambda<1 .
$$

$\lambda$ represents the diminution in the ability to strip as a result of the imposition of the rule of law. $\lambda=0$ implies no diminution.

Thus, when the current state is $N$, the expected current income flow is

$$
\bar{b}(x)=\pi b^{L}+[1-\pi] b^{N}
$$

if the agent builds value, and

if he asset strips.

$$
\bar{s}(x, \theta)=f+\theta[1-\pi(x) \lambda]
$$

We assume that under the rule of law, all agents prefer building value to stripping:

$$
V^{L} \equiv \frac{b^{L}}{1-g} \quad>\quad \frac{s^{L}(\theta)}{1-z} \equiv S^{L}(\theta) \quad \text { for all } \theta .
$$

We also assume, as before, that for a majority of agents, building value under the rule of law is preferred to stripping assets under no rule of law: 


$$
V^{L}>\frac{s^{N}\left(\theta_{\text {median }}\right)}{1-z}
$$

A majority benefits from the rule of law because it controls the misbehavior of others.

The concomitant reduction of each agent's own ability to benefit from opportunism is the price he has to pay. ${ }^{25}$

\section{B. The economic decision}

An agent must decide in every period whether to build value or strip assets. Given (7), he will always build value once the rule of law is established. This leaves him with only the problem what to choose in the no-rule-of-law state. We approach this problem in steps.

Let $W(x, \theta)$ denote the optimal value function of a $\theta$-agent when the current state is $N$ and a fraction $x$ of the agents oppose the rule of law. The Bellman equation is

$$
W(x, \theta)=\begin{array}{r}
\max \left\{\bar{b}(x)+g\left[\pi(x) V^{L}+[1-\pi(x)] W(x, \theta)\right],\right. \\
\bar{s}(x, \theta)+z\left[\pi(x) V^{L}+[1-\pi(x)] W(x, \theta]\right\} .
\end{array}
$$

Building is the optimal policy for this type if

$$
\begin{aligned}
W(x, \theta) & =\bar{b}(x)+g\left[\pi(x) V^{L}+[1-\pi(x)] W(x, \theta)\right] \\
& \geq \bar{s}(x, \theta)+z\left[\pi(x) V^{L}+[1-\pi(x)] W(x, \theta)\right] .
\end{aligned}
$$

Solving for $W(x, \theta)$ using $(10 \mathrm{a})$ and $(10 \mathrm{~b})$, the condition becomes

$$
\Delta(x, \theta) \equiv \underbrace{\bar{b}(x)-\bar{s}(x, \theta)}_{\begin{array}{c}
\text { change in } \\
\text { current income }
\end{array}}+\pi[\underbrace{\pi[g-z] V^{L}}_{\begin{array}{l}
\text { gain in wealth } \\
\text { in state } L
\end{array}}+[1-\pi][\underbrace{g \bar{s}(x, \theta)-z \bar{b}(x)]}_{\begin{array}{l}
\text { gain in wealth } \\
\text { in state } N
\end{array}} \geq 0
$$

\footnotetext{
${ }^{25}$ When the payoff structure satisfies the stronger condition, $V^{L}>s^{N}\left(\theta_{\max }\right) /[1-z]$, then the model is an example of a "common interest game."
} 
To see that the last term corresponds to the "gain in wealth in state $N$," one can compare (11) with the expression obtained by subtracting (10b) from (10a) term by term, which gives $\bar{b}-\bar{s}+\pi[g-z] V^{L}+[1-\pi][g-z] W(x, \theta)$.

A similar analysis can be carried out for stripping assets to be optimal, and it simplifies to a condition in which the inequality in (11) is reversed.

Because $\Delta($.$) is monotonic in \theta$, that is,

$$
\partial \Delta / \partial \theta=-[1-\pi(x) \lambda][1-g(1-\pi(x))]<0
$$

for each $x$ there exists a unique critical value, denoted by $\theta_{a}(x)$, where $\Delta()=$.0 . The identity that defines $\theta_{a}$ represents the "switch line for (economic) action":

$$
\Delta\left(x, \theta_{a}\right) \equiv 0 \quad \text { Switch line for action }
$$

In sum, we have shown that in this model there must be a stationary transition probability from state $N$ to state $L$ that is the outcome of an optimization process, and that there exists a threshold type $\theta_{a}$ below which an agent builds value in every period, obtaining a lifetime expected payoff

$$
V^{N}(x)=\frac{\bar{b}+\pi g \frac{b^{L}}{1-g}}{1-g[1-\pi]}=\frac{\bar{b}}{1-g}+\frac{\pi g}{1-g}\left[V^{L}-V^{N}(x)\right],
$$

and above which an agent strips as long as the no-rule-of-law state prevails, obtaining a lifetime expected payoff

$$
S^{N}(x, \theta)=\frac{\bar{s}+\pi z \frac{b^{L}}{1-g}}{1-z[1-\pi]}=\frac{\bar{s}}{1-z}+\frac{\pi z}{1-z}\left[V^{L}-S^{N}(x, \theta)\right] .
$$


In (14) and (15), the first term in each far RHS expression is the asset value if current expected flows, $\bar{b}$ or $\bar{s}$, continued forever. The next term is the capital gain or loss from transition to the rule of law. In (15), this is a capital gain for the majority of agents. ${ }^{26}$

The proposition below states that the greater the political opposition to the rule of law, the greater the extent of stripping:

Proposition 4. $\frac{d \theta_{a}}{d x}<0$.

Proof. Differentiating (13) gives $\frac{d \theta_{a}}{d x}=-\pi^{\prime} \frac{\partial \Delta\left(x, \theta_{a}\right) / \partial \pi}{\partial \Delta\left(x, \theta_{a}\right) / \partial \theta}$, where

$\frac{\partial \Delta\left(x, \theta_{a}\right)}{\partial \pi}=\left[b^{L}-b^{N}\right][1-[1-\pi] z]+\theta_{a} \lambda[1-[1-\pi] g]+[g-z] V^{L}-[g \bar{s}-z \bar{b}]$.

From (12), $\partial \Delta / \partial \theta<0$ and so the proposition is proved if $\partial \Delta\left(x, \theta_{a}\right) / \partial \pi>0$. An increase in $\pi$ affects the relative return to building value in four ways: it increases current expected income from building value (the first term), decreases the foregone payoff from stripping (the second term), increases wealth if state $L$ occurs (the third term), but lowers wealth if state $N$ persists (the fourth term). To sign (16), note that the last two terms are

$[g-z] V^{L}-\left[g \bar{s}\left(x, \theta_{a}\right)-z \bar{b}(x)\right]=\frac{[1-g][1-z]}{\pi}\left[\frac{\bar{s}\left(x, \theta_{a}\right)}{1-z}-\frac{\bar{b}(x)}{1-g}\right]=[g-z]\left[V^{L}-V^{N}(x)\right]>0$ where the first equality uses (11) and (13) to substitute for $[g-z] V^{L}$, and the second uses (14) and (15) and the fact that in state $N$, an agent of type $\theta_{a}$ is indifferent between stripping and building value. It follows that $\partial \Delta\left(x, \theta_{a}\right) / \partial \pi>0$, as was to be shown.

\footnotetext{
${ }^{26}$ This follows from (8) and (15). Letting $\sigma \equiv[1-z] /[1-z[1-\pi]]$, we have $V^{L}-S^{N}\left(x, \theta_{\text {median }}\right)=\sigma\left[V^{L}-\bar{S}\left(x, \theta_{\text {median }}\right) /[1-z]\right] \geq \sigma\left[V^{L}-S^{N}\left(\theta_{\text {median }}\right) /[1-z]\right]>0$.
} 


\section{The political decision}

Next consider the agent's second problem - to support or oppose the rule of law. Those who build value in the no-rule-of-law state (types $\theta<\theta_{a}$ ) unambiguously benefit from the rule of law: they take the same action in both states and earn higher returns under the rule of law. In contrast, the majority of asset-strippers face a trade-off (recalling footnote 26): their lifetime payoff is $f+\theta-\lambda \theta+z V^{L}$ if the rule of law is established in the present period, and $f+\theta+z S^{N}(x, \theta)$ if it is not. For a given $x$, let $\beta$ denote an assetstripper's net benefit (which could be negative) from prolonging the no-rule-of-law state by one period: ${ }^{27}$

$$
\beta(x, \theta)=\lambda \theta-z\left[V^{L}-S^{N}(x, \theta)\right]
$$

$\beta($.$) is the sum of the immediate benefit and the stream of future effects, with properties$

$$
\begin{aligned}
& \frac{\partial \beta}{\partial \lambda}=\frac{1-z}{1-z[1-\pi]} \theta>0 \\
& \frac{\partial \beta}{\partial x}=z \frac{\partial S^{N}}{\partial \pi} \pi^{\prime}=\frac{-z \pi^{\prime} \beta(x, \theta)}{1-z[1-\pi]} \\
& \frac{\partial \beta}{\partial \theta}=\lambda+\frac{z[1-\pi \lambda]}{1-z[1-\pi]}>0
\end{aligned}
$$

(18a) states that the benefit $\beta$ from prolonging the no-rule-of-law state by one period is larger, the more deeply the rule of law reaches into current returns from stripping. (18b) states that if $\beta>0$, an increase in the political opposition to the rule of law increases $\beta$; if $\beta<0$, it decreases $\beta$. (18c) states that $\beta$ is monotonic in an agent's ability to strip; thus a unique critical value of $\theta$, denoted $\theta_{p}$, exists at which $\beta=0$ :

\footnotetext{
${ }^{27}$ We treat (17) as if it is defined over all $\theta$, but it affects behavior only through (21), i.e., when $\theta_{p}>\theta_{a}$. See Figure 6A.
} 


$$
\beta\left(x, \theta_{p}\right) \equiv 0 .
$$

It is easy to check that

$$
\frac{d \theta_{p}}{d \lambda}=-\frac{\partial \beta / \partial \lambda}{\partial \beta / \partial \theta}<0, \quad \frac{d \theta_{p}}{d x}=-\frac{\partial \beta / \partial x}{\partial \beta / \partial \theta_{\left.\right|_{\beta=0}}}=0 .
$$

An agent's opposition to the establishment of the rule of law is increasing in $\lambda$ and is invariant to the current political environment (i.e. to the opposition of others).

We are now ready to define the "political switch line," $\theta^{*}(x)$, such that agents of type $\theta<\theta^{*}$ demand establishment of the rule of law and agents of type $\theta>\theta^{*}$ oppose it.:

$$
\theta^{*}(x) \equiv \operatorname{Max}\left\{\theta_{a}, \theta_{p}\right\} \quad \text { Political switch line }
$$

\section{Equilibrium}

An equilibrium is defined by the size of the constituency $(x)$ that in each period opposes transition to the rule-of-law state. An equilibrium solves $x^{*}=1-H\left(\theta^{*}\left(x^{*}\right)\right)$.

Figure 6A depicts the two "switch lines" in the space $x$ and $\theta$. Since $d \theta_{a} / d x<0$ and $d \theta_{p} / d x=0$, the switch lines may cross. In that case, they demarcate the three areas depicted in the figure. In Area I, agents build value and support the rule of law. In Area II, they strip assets and oppose the rule of law. In Area III, $\theta_{a}(x)<\theta<\theta_{p}$ : agents strip and support the rule of law; for these values of $\{x, \theta\}$, the capital gain from establishment of the rule of law exceeds the loss of stripping income.

Figure 6B shows the "political switch line," $\theta^{*}(x)$, and the stripping ability curve. An interior equilibrium occurs as a pair $\left(x, \theta^{*}\right)$ at which the two curves intersect. Comparing Figures 3 and $6 \mathrm{~B}$ shows what difference is made by the dynamics and the possibility that someone who finds it optimal to strip assets under the prevailing conditions would still prefer to have a regime of law, and will vote for it. Generally, the 
bad equilibrium becomes less bad (lower $x$ and higher $\theta^{*}$ ).

The next proposition characterizes the set of equilibria.

Proposition 5 An equilibrium always exists. If $\theta_{p}<\theta_{a}$ and if $0<x^{*}<1$ is an equilibrium where

$$
-h\left(\theta^{*}\left(x^{*}\right)\right) \frac{d \theta_{a}}{d x} \geq 1,
$$

then there are also at least two other equilibria, one with a greater and one with a lower probability of the rule of law. On the other hand, if $\theta_{a}<\theta_{p}$ or if at every equilibrium, $-h\left(\theta^{*}\left(x^{*}\right)\right) d \theta_{a} / d x<1$, then the equilibrium is unique.

Proof. $\phi(x)=1-H\left(\theta^{*}\right)-x$ satisfies $\phi(0) \geq 0, \phi\left(x^{*}\right)=0$, and $\phi(1) \leq 0$ and is continuous. $\phi^{\prime}\left(x^{*}\right)>0$ if and only if $\theta_{p}<\theta_{a}$ and inequality (22) holds.

It should now be clear how multiple equilibria could arise in a dynamic setting even with infinitely far-sighted agents and even when the equilibria are Pareto ranked (i.e. the condition in footnote 25 holds). If the expected probability of transition to the rule of law is low, the relative return to building value is low: both the current income and the expected return to increasing the asset base are low. Thus many agents will rationally strip and, given that, some will vote against the rule of law if its "reach" into stripping returns is high (taking into account as well the reduced asset base on which they have to build). ${ }^{28}$ This can make the no-rule-of-law regime persist.

Conversely, if the expected probability of transition to the rule of law is high, then the relative return to building value is high for two reasons: the current relative payoff from building value is high, and the long-run return to building up the asset base is high. In

${ }^{28}$ A single agent's vote has a negligible effect on the probability that the rule of law is established; therefore in choosing his economic action, he ignores the effect of his economic decision on how he himself votes, how other people believe the system will evolve and, thus, how others invest and vote. There are two "market failures" associated with the public good nature of votes. 
such a case, many (possibly all) agents will build value in the current period. Such agents unambiguously gain from the rule of law, and so a strong political constituency for the rule of law may also be an equilibrium.

\section{E. Effect of initial conditions and policy}

In this section we characterize the comparative dynamics of equilibrium. Our results parallel Proposition 4 and make use of the same notation: $(i) H=H(\theta ; \varepsilon)$ with $H_{\varepsilon}<0$, which means that an increase in $\varepsilon$ shifts $u p$ the stripping ability curve; (ii) $I^{j}=I^{j}(\alpha)$ with $d I^{j} / d \alpha<0$ - an increase in $\alpha$, raising the net return to building value, shifts up the "political switch line"; and (iii) $\pi(x ; \gamma)$ with $\pi_{\gamma}>0$ - an increase in $\gamma$, raising the probability of the transition to rule of law weakly shifts up the political switch line.

Proposition 6. Evaluated in the neighborhood of a stable equilibrium $x \in(0,1)$, $d x / d \mathcal{E}>0, \quad d x / d \alpha<0, \quad$ and $d x / d \gamma \stackrel{\lfloor}{=}$ as $\theta_{a} \gtreqless \theta_{p}$.

Proof. See the appendix.

The proposition states that opposition to the rule of law is increasing in the payoff to stripping, decreasing in the net payoff to building value, and weakly decreasing in the probability of the transition. The last result is new. If $\theta^{*}=\theta_{p}$, then an increase in the transition probability will reduce asset-stripping (from Prop. 4) but will not affect the constituency opposed to the rule of law. This is true because (a) in the initial equilibrium the marginal asset-stripper supports the rule of law and (b) the increase in the transition probability does not shift the "political switch line" in a neighborhood of the equilibrium.

In the dynamic model, a change in parameters has stark implications for growth. A factor that lowers the equilibrium probability of transition from, say, $\pi$ to $\underline{\pi}$, increases the expected duration of the no-rule-of-law state from $1 / \pi$ to $1 / \underline{\pi}$. An economy that 
experiences a long period of no rule of law will always be poorer than another economy with the same initial wealth but a less prolonged experience without the rule of law; see Figure 7. ${ }^{29}$ We mention two examples that extend our discussion in Section 3.

The natural resource "curse." We argued above that an exogenous increase in the share of an economy's assets in natural resources (rather than industrial assets) would tend to increase the relative returns to asset-stripping. This effect lowers $H(. ; \varepsilon)$, which increases the constituency in favor of prolonging the no-rule-of-law state. The model thus suggests a new mechanism to explain why, given initially weak institutions, an economy based on natural resources - especially oil, gas and minerals, which are relatively easy to strip - might be less likely to develop a strong political constituency for institutions broadly beneficial to economic development (the rule of law).

Macroeconomic policy. Big Bang reforms rested upon the hope that if one privatized assets, freed relative prices, and stabilized the price level, then the creation of market-supporting institutions, including the rule of law, would follow in due course. The next example demonstrates, on the contrary, that a narrow focus on stabilization can block the transition to the rule of law if it reduces the relative returns to building value.

Suppose that there is a simple majority voting rule: $\pi=0$ for $x>1 / 2$, otherwise $\pi$ $=1$, so the tipping point is a population fraction $\hat{x}=1 / 2$. Associated with the tipping point is a type $\hat{\theta}$. Suppose finally that $\hat{\theta}>\theta_{p}$. (This inequality is satisfied if $\lambda$ is sufficiently large or $z$ is sufficiently small.)

Consider the agent of type $\hat{\theta}$. If he chooses to strip in the no-rule-of-law state, $\pi$ $=0$ and his lifetime payoff is $S^{N}(\hat{\theta})=s^{N}(\hat{\theta})+z S^{N}(\hat{\theta})$. If he chooses to build

\footnotetext{
${ }^{29}$ Our simplifying assumption of constant returns to investment is what leads to this stark result.
} 
value, then $\pi=1$ and his lifetime payoff is $V^{L}=b^{L}+g V^{L}$.

Government chooses public spending $G$ and through monetary policy affects the interest rate $r$. For reasons discussed in Section 3, the interest rate influences the relative return to building value. Under plausible circumstances, raising $r$ lowers this return. For simplicity, suppose that the level of $G$ does not affect the relative return to building value. (This would be easy to generalize.) Then the rule of law will be established if and only if

$$
\frac{s^{N}(\hat{\theta}, r)}{1-z} \leq \frac{b^{L}(r)}{1-g} .
$$

Rule-of-law constraint

Equating the two sides of this inequality defines a critical value of the interest rate, $\hat{r}$. The "rule of law constraint" is $r \leq \hat{r}$.

As in standard macroeconomics, suppose social welfare $W$ depends on the growth rate $(g)$, the level of social expenditures $(E)$, and inflation $(i): W=W(g, E, i)$. Postulate that these three variables are in turn determined by $r$ and $G$, which enables us to write the indirect social welfare function $\Omega(r, G)$. A possible shape for the iso-welfare curves is depicted in Figure 8, with the social optimum at point $P$ where $\Omega_{r}=0$ and $\Omega_{G}=0$.

This paper poses a fundamental objection to the traditional approach, which is that the structural equations relating $\{g, E, i\}$ to the policy variables $\{r, G\}$ depend on the institutional structure, which itself is endogenous. In particular, we assume that social welfare under the rule of law $(L)$ is so much higher than under no rule of law $(N)$ that we need only focus on the rule-of-law state. But then we must recognize that $\{r, G\}$ must be chosen so that the rule of law emerges as part of the political equilibrium. This requires that $r \leq \hat{r}$, as defined above. (The iso-welfare curves are dashed in the policy region where the rule of law is unattainable.) Now social welfare is maximized at point $P^{\prime}$. 
In this case, defenders of tight monetary policies in Russia who said that the problem was not the policies, but the weak Russian institutions, are missing the mark. If our analysis is correct, the institutions themselves were affected by the macroeconomic policies, and in a way that was adverse to the creation of a rule of law.

\section{Discussion of the assumptions}

This section examines more closely the key assumptions of the model.

Intertemporal effects. We examine first the assumption that today's political state affects today's economic action, and that today's economic action affects one's vote for the political regime that will prevail next period. In two limiting cases, such a link might not exist. First, if $\lambda$ equals zero, then there is no effect of the rule of law on today's return. Everyone will, accordingly, vote for what is in his best long-term interests. We believe that, in practice, the rule of law does affect the amounts that can be stripped, so that $\lambda$ is greater than zero. $\lambda$ greater than zero means that the rule of law inhibits an agent's ability to strip in the period that just ended; i.e., the rule of law circumscribes certain actions used by strippers to maximize their returns.

In fact, we believe our model underestimates the importance of the links between what happens today and in the future. The rule of law is based on not only statutes but also morality: Not just any principle of distributing property rights can be an element of the rule of law in a democracy (Fuller 1968, Dahl 1990). A commitment to the rule of law today may proscribe certain rules for distributing state assets today, and those who believe that they will obtain more assets under "no rule of law" will thus oppose the rule of law. ${ }^{30}$ Moreover, a democracy cannot make a credible commitment to a distribution of property

\footnotetext{
${ }^{30}$ As noted earlier, implicitly we are assuming that those who have a comparative advantage in stripping also will, on average, receive more from distributions in the no-rule-of-law state.
} 
rights that is widely viewed as illegitimate. ${ }^{31}$ This diminishes the value of the rule of law and, in particular, encourages asset stripping even under the rule of law by those who have obtained their assets illegitimately.

The other possibility is that the prospect of the rule of law in the future always induces individuals to take actions today to maximize the long-run value of their assets. This might be the case, for instance, if there were perfect capital markets (with nongovernmental enforcement). With perfect capital markets and the prospect of the establishment of the rule of law in the future, it would be in the interests of each individual to take actions that maximize the value of assets because he could "capture" that value. This may have been the economic model in the minds of those who believed in the Coasian analysis; but the whole issue of transition concerns the sequencing and pacing of reforms and institution creation. Privatization occurred prior to the creation of effective capital markets; the gradualists emphasized the dangers of privatizing before market-supporting infrastructure existed, the shock therapists ignored their warnings.

Ironically, with imperfect capital markets, the belief that the rule of law might eventually be established might lead to even more, and more inefficient, asset stripping than our simplified model suggests. Stripping assets ensures that assets appropriated illegitimately from the State would not be reappropriated. The historian Orlando Figes (1996) describes how, in a Russian town on the weekend between the departure of the White Army and the arrival of the Red Army in 1920, the citizens stripped the streets of the trees. The announcement in Brazil that restrictions were about to be imposed to

\footnotetext{
${ }^{31}$ Technically, this means that the value of an asset under the rule of law depends in part on how it was obtained; if it is obtained through a privatization procedure that is viewed as illegitmate, then there is a certain probability that it will be reappropriated by the state, even under the rule of law. This greatly complicates the mathematics.
} 
prevent environmentally unsound logging may have exacerbated such unsound logging in the short run. In Russia, those controlling assets, especially with uncertain long-term rights, had an incentive to strip assets quickly, before they either lost those rights or before controls (such as those associated with the export of capital) were imposed. ${ }^{32}$ The manner of privatization in Russia may have exacerbated these problems, with control of many of the enterprises in the hands of older individuals who would retire before there was a likelihood that a good capital markets would be in place. For them, the only way of realizing value from control was stripping, rather than wealth creation. ${ }^{33}$

Stationary transition probability. In the model a stationary transition probability to the rule-of-law state always exists. There are a variety of arguments for why things might not be as stationary as we model them.

First, the model assumes that there are only two possible activities: to strip or build value. If, alternatively, there was a subsistence, stand-alone activity that agents could undertake in the no-rule-of-law state, then ultimately that activity would be adopted by everyone as the asset base was depleted (a stationary value of $\pi$ would not exist); in the long run no one would oppose the rule of law. A second assumption, which we made because it greatly simplifies the analysis, is that of constant returns to investment. If, alternatively, marginal returns to assets increase as the level of assets decreases, as in standard growth analysis, then as more and more funds are taken out of the economy, the

\footnotetext{
${ }^{32}$ In that sense, the belief that the rule of law would be introduced not immediately, but in the intermediate term, represented the worst of all possible worlds. If it were believed that the rule of law were to be introduced only in the very long run, a more efficient pattern of asset stripping could emerge. If it were believed that the rule of law were to be introduced very quickly, then it might not pay to asset strip at all, given the high value of assets under the rule of law.

${ }^{33}$ In contrast, in Poland, where privatization was conducted more slowly, with large enterprises broken into smaller units, control was more frequently in the hands of younger individuals, for whom there were larger returns from longer term investments, and for whom there was a greater prospect of the creation of effective capital markets prior to retirement.
} 
capital stock is so depleted that the attractiveness of foreign direct investment and reinvestment of profits, and thus of the rule of law, increases. On both grounds, the prognosis for the rule of law is not as bleak as this model might suggest.

However, the assumptions of the model regarding the asset base and beliefs have the opposite bias. First, we assumed that the distribution of stripping abilities was exogenous. Given Russia's vast natural resources, in ten years Russia will still be rich in natural resources. A bad situation — characterized by a high relative return to strippingcould worsen because the value of man-made capital (machines, buildings, equipment) tends to deteriorate more quickly than that of natural resources under a stripping/nomaintenance strategy. Deindustrialization is rapidly progressing within Russia (recall footnote 19). It may shift the distribution of types, among those who control assets, toward those with greater ability to strip. One could thus argue that the incentives to strip are increasing over time and that the prognosis for the rule of law is actually worse than this model might suggest.

Another assumption of the model is that beliefs are independent of events that occur after the Big Bang. But the experience of the transition may reinforce one or another view of man; one can learn not to trust. The experience of low or high levels of corruption can guide expectations with respect to the equilibrium that will be achieved. ${ }^{34}$ Further, populations that experience different levels of corruption over prolonged

\footnotetext{
${ }^{34}$ Experimental economics has addressed the question of what happens when large groups of individuals repeatedly play a coordination game with multiple equilibria. Recent results (van Huyck et al 1990, Crawford 1991) highlight two conclusions: (a) The outcomes are history-dependent. Contrary to Schelling's suggestion, players do not necessarily coordinate on the efficient outcome; rather, it is the happenstance of the initial play that seems to play a key role. (b) In some cases, the "risk dominant" equilibrium emerges over repeated plays and is then played virtually all the time. This is the equilibrium with the lowest strategic risk in the sense of being most robust to uncertainty about the other players' actions. As each realizes, or comes to believe, that this is the strategy that others will pursue, this becomes the unique equilibrium, even though it may be very inefficient.
} 
periods are likely to exhibit different behaviors because the level of corruption affects the way behavior is evaluated. The response of a Russian minister to allegations of corruption is illustrative of such an effect: ${ }^{35}$

Vladimir Rushaylo has flatly denied the allegations that 70 per cent of all Russian officials are corrupted ... "Only those who have links with the organized criminal gangs can be regarded as corrupted officials. Do not mistake bribe-taking for corruption," the Russian Interior Minister stressed.

(RIA news agency, Moscow, March 13, 2001/BBC Monitoring ( $\mathrm{BBC}$ )

In limiting cases, e.g. Russia, where high levels of criminal activity were used to obtain control rights, there may be still another reason why it is difficult to exit from the no-rule-of-law state. For those who engaged in criminal activity, the switch to the rule of law may not entail an increase in the net returns they can appropriate because of the risk of retroactive criminal prosecution. Recognizing the huge cost associated with the transition to the rule of law, these individuals may "invest" a great deal in the maintenance of no rule of law, including killing those who work to establish the rule of law. Not only are some individuals locked in by their pasts, but others who might wish to support the rule of law may incur tremendous risks in doing so. ${ }^{36}$ History matters.

\footnotetext{
${ }^{35}$ There are two strands of thought suggesting that one should be unconcerned with corruption. One is the principal subject of this paper: that it matters little how property rights are established, only that they be established. The other likens corruption to an auction. With robust competition, the assets are "sold" to the highest bidder. In this perspective, bribe-taking improves economic efficiency and thus is not a "bad" form of corruption. The only conditions under which such a conclusion might hold would be those in which markets worked well, e.g. because there was perfect information, in which case the issue of corruption itself would simply not arise. Theoretical and empirical work finds that more bribe payments give rise to more regulatory burden: Corrupt politicians create regulations so that they can release firms from them in exchange for bribes (Kaufmann and Wei 1999 and Laffont and Martrimort 1999), while firms bribe government to take actions that restrain competition (Hellman, Jones, and Kaufmann 2000).

${ }^{36}$ The assassination in August 2002 of V. Golovlyov, a member of parliament, is one of a long list of assassinations, nearly all unsolved, of Russian government officials who had links with criminal activities. Reportedly, "Mr. Golovlyov was killed by former cronies because he had jumped [from a criminal past] to the side of the law helping the investigators." (Michael Wines, "Politics in Moscow More Dagger than Cloak," New York Times, August 24, 2002, pp. A1-4.)
} 


\section{Conclusion}

This paper has made a small step forward by treating a variable that was previously treated as exogenous as endogenous - the political environment (the rule of law). The model analyzed here, in which no individual or subgroup has the power to establish their own limited version of law and order, one which favors them at the expense of others, is a setting that we would interpret as very favorable to the emergence of the "rule of law." Yet we have shown that under these seemingly favorable conditions, Big Bang reforms may well not create a constituency for the rule of law. We have shown that this would be the case even if the Big Bang had been managed in ways that did not give rise to an oligarchy, a small group able to shape the institutional, including legal, environment in ways that advantage them at the expense of the rest of society. ${ }^{37}$

At one level of analysis, our results are hardly surprising. There was no reason, on the basis of theory or history, to expect that the privatization of control rights would lead to the rule of law_a legal framework that would promote economic efficiency in a market economy. Russia showed that incentives did matter but that if the economic and political environment was not well designed, the incentives created by Big Bang privatization could lead to asset stripping rather than wealth creation, and to the perpetuation of a regime that was far from what would, in ordinary parlance, be called a rule of law. Without privatization, control resided in the hands of government officials, who might also have stripped assets (the process occurred widely under perestroika and came to be known as "spontaneous privatization"). The point is that their ability to strip was enhanced by official privatization; before official privatization, a too greedy

\footnotetext{
${ }^{37}$ In that sense, it should be emphasized, the analysis here is not directly applicable to the situation in Russia, where an oligarchy did emerge.
} 
government official could be dismissed from a state post and thereby lose the privileges attached to it. Official privatization did entail the transfer of control rights, which did make a difference.

The contribution of the paper is to show that the view that once stripping has occurred, the strippers will say "enough" and by supporting the rule of law seek public protection of their gains, is flawed. By abstracting from the obvious problem that strippers who obtain great wealth can buy special favored treatment from the state, we highlight the two less obvious flaws in the optimistic view about the Big Bang: First, that the asset-strippers can remove the assets from exposure to further stealing, and in that case they do not care about public protection for their gains (formally, $z>0$ ). And secondly, that an assignment ${ }^{38}$ of property rights that conflicts with a society's view of fairness undercuts the moral credibility of the law and so engenders subversion. The perceived justice of a system is important to gaining the cooperation of those involved in the process of producing the rule of law (judges, regulators, jurors, potential offenders, etc.). Accordingly, state protection of asset strippers may be infeasible, even under an ostensible rule of law (formally, $\lambda>0$ ). Knowing this, strippers will be less supportive of the rule of law.

Our dynamic model makes one further point: what is at issue is how fast the rule of law will emerge. The presumption of the Big Bang strategy was that the faster state property was turned over to private hands, the faster a true market economy, including the rule of law, would be established. Our analysis shows that, even if eventually a rule of law is established, the Big Bang may put into play forces that delay the establishment

\footnotetext{
${ }^{38}$ Including the processes by which those assignments were made.
} 
of the rule of law. The tortoise once again may beat the hare!

We have described the impact on the political equilibrium - and thus on the economic equilibrium — of certain policies, such as the particular structure of privatization and monetary policy. In a fuller analysis, these policies would themselves be viewed as endogenous. To be sure, international institutions and other outsiders promoted rapid privatization, capital market liberalization, and tight monetary policies. But at least some of these policies served particular interests, and those interests might have prevailed even without outside pressure. This is only one of several difficult issues in counterfactual history, which it is not the intent of this paper to address. ${ }^{39}$

Where do we go from here? There are hysteresis effects; we cannot turn back history. Our model provides a framework for thinking about what kinds of policy changes, given that history, might be most conducive to the creation of a constituency for the rule of law. Policies that enhance the returns to investment and wealth creation rather than asset stripping not only serve to strengthen the economy in the short run, but enhance political support for the rule of law and thus put it in a position for stronger longterm growth. The analysis of this paper details the kinds of concrete policy changes with these desired impacts.

\footnotetext{
${ }^{39}$ Clearly rapid privatization served the interests of those who seized control as a result. Perhaps without outside pressure, there would have been even more insider privatizations. While our analysis cannot fully answer such questions, it provides a framework for exploring the further ramifications. If the insider privatizations had more political legitimacy than the loans-for-shares privatization (they could hardly have less legitimacy), then it might have been easier to provide security for those insiders who invested inside the country rather than sending their assets abroad, in which case there would have been more political support for the rule of law, and thus a "better" political and economic equilibrium might have emerged.
} 


\section{References}

Anderson, Annelise. "The Red Mafia: A Legacy of Communism," in: Edward P. Lazear, ed. Economic Transition in Eastern Europe and Russia. Stanford, CA: Hoover Institution, 1995, pp. 340-367.

Aslund, Anders, and Mikhail Dmitriev. "Economic Reform vs. Rent Seeking," in Russia after Communism, A. Aslund and Martha Olcott, eds., Carnegie Endowment for International Peace: Washington, DC, pp. 91-130, 1999.

Black, Bernard, Reinier Kraakman, and Anna Tarassova. "Russian Privatization and Corporate Governance: What Went Wrong?" Stanford Law Review, 2000.

Blanchard, Olivier and Michael Kremer. "Disorganization." Quarterly Journal of Economics, 1997.

Blasi, Joseph R., Maya Kroumova, and Douglas Kruse. Kremlin Capitalism: Privatizing the Russian Economy, Ithaca, NY: Cornell University Press, 1997.

Buiter, W. "From Predation to Accumulation? The Second Transition Decade in Russia," Economics of Transition 8 (3), 2000, pp. 603-622.

Crawford, Vincent P. “An 'Evolutionary' Interpretation of Van Huyck, Battalio, and Beil's Experimental Results on Coordination," Games and Economic Behavior 3(1), February 1991, pp. 25-59.

Dahl, Robert A. After the Revolution? Authority in a Good Society, Revised edition. New Haven: Yale University Press, 1990.

de Meza, David, and J. R. Gould. "The Social Efficiency of Private Decisions to Enforce Property Rights," Journal of Political Economy 100 (3), 1992, pp. 561-80.

Dewatripont, Mathias and Gerard Roland. "The Virtues of Gradualism and Legitimacy in the Transition to a Market Economy," Economic Journal 102, 1992, pp. 291-300.

. "The Design of Reform Packages under Uncertainty," American Economic Review, December 1995, pp. 1207-1223, 1995.

Engerman, Stanley L. and Kenneth Sokoloff. "Factor Endowments, Inequality, and Paths of Institutional and Economic Development among New World Economies," Economia 3, Fall 2002 (forthcoming).

European Bank for Reconstruction and Development (EBRD). Transition Report 2000, 2001. London, UK, 2001, 2002.

Figes, Orlando. A People's Tragedy: The Russian Revolution, New York: Penguin, 1996.

Freeland, Chrystia. Sale of the Century: Russia's Wild Ride from Communism to Capitalism. New York: Random House, 2000.

Frydman, Roman, Katharina Pistor, and Andrzej Rapaczynski. "Exit and Voice after Mass Privatization: The Case of Russia," European Economic Review, 40, 1996, 581-588.

Frydman, Roman, Kenneth Murphy, and Andrzej Rapaczynski. Capitalism with a Comrade's Face. Budapest Central European University Press, 1998.

Frye, Timothy. Brokers and Bureaucrats: Building Market Institutions in Russia, Ann Arbor: The University of Michigan Press, 2000.

Fuller, Lon L. Anatomy of the Law. New York: Praeger, 1968.

Gellner, Ernest. Conditions of Liberty, New York: Penguin Press, 1994.

Glaeser, Edward, Simon Johnson and Andrei Shleifer. "Coase versus the Coasians" Quarterly Journal of Economics CXVI (3) 2001, 853-99. 
Gray, Cheryl and Kathryn Hendley, "Developing Commercial Law in Transition Economies: Examples from Hungary and Russia,” in: Jeffrey Sachs and K. Pistor, eds.1997, 139-164.

Greenwald, Bruce and Joseph E Stiglitz. "Externalities in Economics with Imperfect Information and Incomplete Markets." Quarterly Journal of Economics 1986 (May): 229-64.

Greif, Avner. "Cultural Beliefs and the Organization of Society: A Historical and Theoretical Reflection on Collectivist and Individualist Societies," Journal of Political Economy, 102 (5), 1994, pp. 912 - 50.

Haltiwanger, John and Michael Waldman. "Responders versus Non-Responders: A New Perspective on Heterogeneity," Economic Journal 101 (Sept.). 1991, 1085-1102.

Hellman, Joel. "Winners Take All - The Politics of Partial Reform in Postcommunist Transitions," World Politics 50 (January 1998), 203-234.

Hellman, Joel and Mark Schankerman. "Intervention, Corruption and Capture," Economics of Transition 8 (3), 2000, pp. 545-576. , Geraint Jones, and Daniel Kaufmann. "Seize the State, Seize the Day': State Capture, Corruption, and Influence in Transition," World Bank Policy Research Working Paper No. 2444, 2000.

Hoff, Karla and Joseph E. Stiglitz. "Modern Economic Theory and Development," in: Gerald Meier and Stiglitz, eds. Frontiers of Development Economics. Oxford: Oxford University Press, 2001, 389-459.

"The Political Economy of Property Rights in the Transition

Economies: The Role of New Entry," World Bank, manuscript, 2002.

Hoffman, David E. The Oligarchs, New York: Public Affairs, 2002.

Johnson, Simon, Daniel Kaufmann, and Andrei Shleifer. "The Unofficial Economy in Transition," Brookings Papers on Economic Activity, 2:1997.

Johnson, Simon, John McMillan, and Christopher Woodruff. "Property Rights and Finance," NBER Working Paper No. 8852, 2002.

Kaufmann, Daniel, and Shang-Jin Wei. "Does 'Grease Money' Speed Up the Wheels of Commerce?” NBER Working Paper No. 7093. April 1999.

Kitschelt, Herbert. "Post-Communist Economic Reform: Causal Mechanisms and Concomitant Properties," Duke University, manuscript, 2001.

Klebnikov, Paul. Godfather of the Kremlin: Boris Berezovsky and the Looting of Russia, New York: Harcourt, 2000.

Laffont, Jean-Jacques, and David Martimort. "Separation of Regulators against Collusive Behavior," RAND Journal of Economics, 30 (2), 1999, 232-62.

Ledeneva, Alena V. Russia's Economy of Favours, Cambridge, Cambridge University Press, 1998

Lieberman, Ira and Rogi Veimetra. "The Rush for State Shares in the 'Klondyke' of Wild East Capitalism: Loans-for-Shares Transactions in Russia," George Washington Journal of International Law and Economics, 29, 3, 1996, p. 739.

Loungani, Prakash, and Paolo Mauro. "Capital Flight from Russia," The World Economy, 24 (5), pp. 689-706, 2001.

Murphy, Kevin M., Andrei Schleifer, and Robert W. Vishny "Why Is Rent-Seeking So Costly to Growth?" American Economic Review 83, May 1993, 409-14. 
Platteau, Jean-Philippe. Institutions, Social Norms, and Economic Development. Amsterdam, Harwood Academic Publishers 2000.

Przeworski, Adam. Sustainable Democracy. Cambridge: Cambridge U. Press, 1995.

Robinson, James, Ragnar Torvik, and Thierry Verdier. "Political Foundations of the Resource Curse," CEPR Working Paper No. 3422, 2002.

Roland, Gerard, and Thierry Verdier. "Law Enforcement and Transition," CERGE-EI Working Paper 22, 1999.

Ross, Michael. "The Political Economy of the Resource Curse," World Politics 51, 1999, 297-322.

Shleifer, Andrei. and Robert W. Vishny. The Grabbing Hand - Government Pathologies and their Cures. Cambridge, MA: Harvard University Press, 1998.

Stoner-Weiss, Kathryn. "The Limited Reach of Russia's Party System: Underinstitutionalization in Dual Transitions," Politics and Society 29 (3), 2001, 385-414.

Wood, Gordon S. The Radicalism of the American Revolution: How a Revolution Transformed a Monarchical Society into a Democratic One Unlike Any that Had Ever Existed, New York: Random House, 1991.

van Huyck, John B., R.C. Battalio, and R.O. Beil. "Tacit Coordination Games, Strategic Uncertainty, and Coordination Failure," American Economic Review 80(1), 1990, $234-48$. 


\section{Appendix A. Static Model}

\section{Proof of Prop. 2}

(i). An equilibrium is a value of $x$ such that

$$
x=1-H\left(\theta^{*} ; \varepsilon\right)
$$

with $\theta^{*}(x)=g-\pi(x ; \gamma) I^{L}(\alpha)-[1-\pi(x ; \gamma)] I^{N}(\alpha)$. (3) does not hold at a stable equilibrium, which implies: $0<1+h d \theta^{*} / d x \equiv D$. Using the implicit function theorem gives
(a) $\frac{d x}{d \varepsilon}=-\frac{H_{\varepsilon}}{D}>0$;
(b) $\frac{d x}{d \alpha}=\frac{h}{D}\left[\pi \frac{d I^{L}}{d \alpha}+(1-\pi) \frac{d I^{N}}{d \alpha}\right]<0$;
(c) $\frac{d x}{d \gamma}=\frac{h \pi_{\gamma}}{-D}\left[V^{L}-V^{N}\right]<0$.

(ii) $D<1$ proves the result.

\section{Proof of Prop. 3}

In the "mixed case," the marginal agent who strips has type $\theta^{\text {mixed }}$, defined by

$$
\theta^{\text {mixed }}=g-\pi\left(1-H\left(\theta^{\text {mixed }}\right)\right) I^{L}-\left[1-\pi\left(1-H\left(\theta^{\text {mixed }}\right)\right)\right] I^{N}
$$

Suppose the proposition is false, so $x^{\text {mixed }} \geq[1-p] \mathrm{x}^{*}$. Only opportunistic agents asset strip. This implies that an increase in the fraction of strippers above $[1-p] x^{*}$ is due to an increase in the fraction of opportunistic agents who strip, so (A3) implies $\theta^{\text {mixed }} \leq \theta^{*}$.

The presence of agents with civic virtue is equivalent to an atom at $\theta=-\infty$. This shifts up $H(. ; \varepsilon)$ and, from Proposition 2, reduces the fraction of opportunistic agents who strip. This implies $\theta^{\text {mixed }}>\theta^{*}$, a contradiction, which proves the result. 


\section{Appendix B. Dynamic Model}

Proof of Prop. 6. The proof is in four steps and follows the lines of the proof of Prop. 2.

First, we show that $D>0$. From (21), $\theta^{*} \equiv \operatorname{Max}\left\{\theta_{a}, \theta_{p}\right\}$. If $\theta^{*}=\theta_{p}, d \theta^{*} / d x=0$ from (20) so $D=1$. If $\theta^{*}=\theta_{a}$, then, at a stable equilibrium, (22) does not hold, so $D>0$.

Second, we implicitly differentiate (A1) with respect to $x$ and $\varepsilon$, which yields an expression identical to equation (A2-a).

Third, we consider the case where $\theta^{*}=\theta_{a}$ and implicitly differentiate (A1) with respect to $x, \alpha$, and $\gamma$. Using (5), (7), and (11)-(13), we obtain

$$
\frac{d x}{d \alpha \theta^{*}=\theta_{a}}=-\frac{h}{D \partial \Delta / \partial \theta}\left\{\pi\left[1-z[1-\pi]+\frac{g-z}{1-g}\right] \frac{d I^{L}}{d \alpha}+[1-\pi][1-z[1-\pi]] \frac{d I^{N}}{d \alpha}\right\}<0
$$

and

$$
{\frac{d x}{d \gamma_{\mid \theta^{*}=\theta_{a}}}}=\frac{h \pi_{\gamma}}{D}\left[\frac{\partial \Delta / \partial \pi}{\partial \Delta / \partial \theta}\right]<0
$$

The last step is to consider the case where $\theta^{*}=\theta_{p}$, and again implicitly differentiate (A1) with respect $x, \gamma$ and $\alpha$. Using (17) and (19), we obtain

$$
\left.\frac{d x}{d \alpha}\right|_{\theta^{*}=\theta_{p}}=\frac{h z}{D \partial \beta / \partial \theta} \frac{1-z}{1-z[1-\pi]}\left[\frac{\partial I^{L} / \partial \alpha}{1-g}\right]<0
$$

and

$$
{\frac{d x}{d \gamma_{\mid \theta^{*}=\theta_{p}}}}=\frac{-h z \pi_{\gamma}}{D \partial \beta / \partial \theta}\left[\frac{\beta\left(x, \theta_{p}\right)}{1-z[1-\pi]}\right]=0
$$

since $\beta\left(., \theta_{p}\right)=0$. 
Figure 1. Growth and property rights insecurity in 20 transition economies

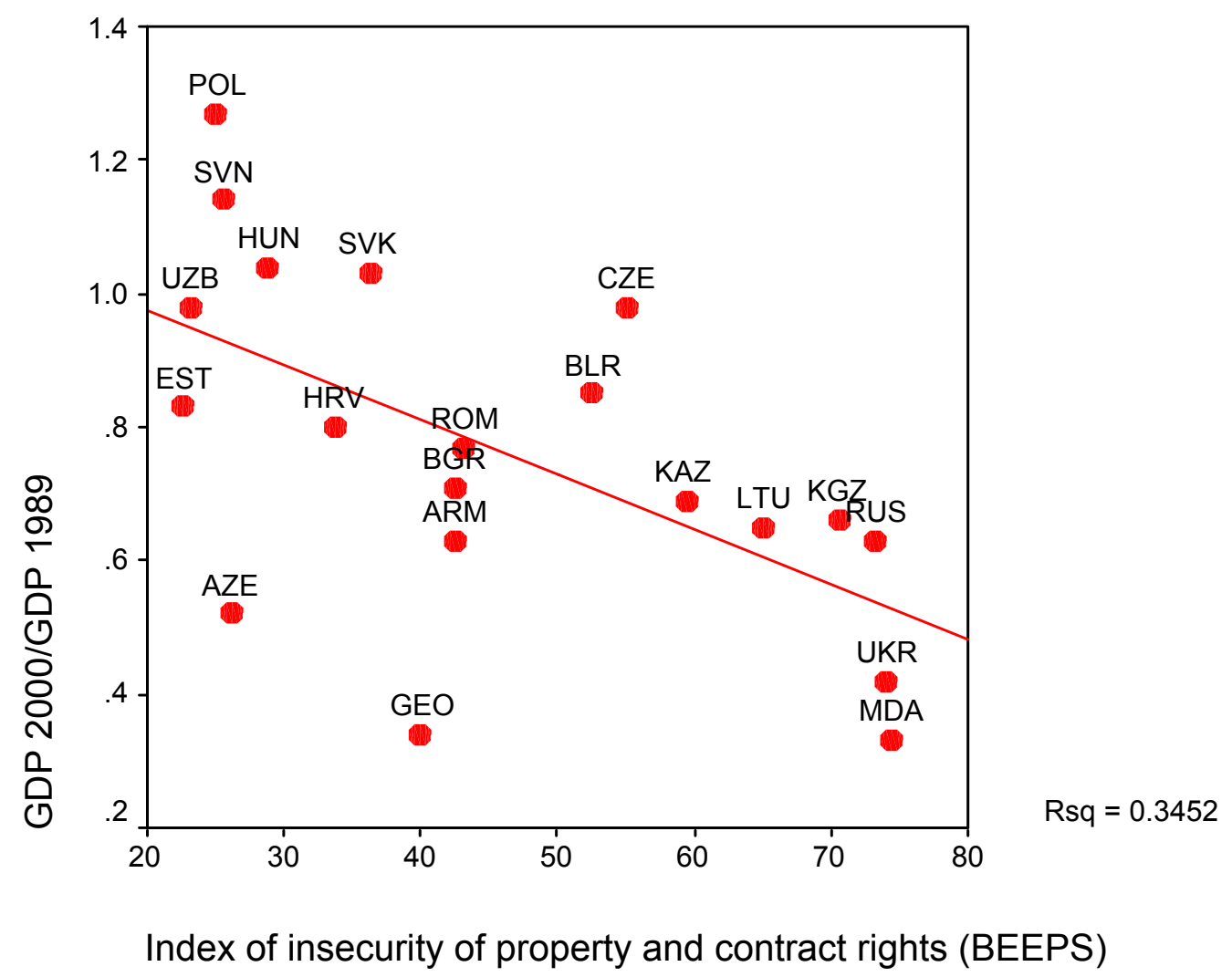

Note: The index of insecurity is the fraction of respondents who disagree with the statement: "I am confident that the legal system will uphold my contract and property rights in business disputes." Response categories are "agree in most cases, tend to agree, tend to disagree, disagree in most cases, strongly disagree." In constructing the index, the response "tend to disagree" is counted as disagreement.

Source: For the GDP data, EBRD 2001. For the survey data, http://www.worldbank.org/wbi/governance/beepsinteractive.htm. The survey is documented and analyzed in Hellman, Jones and Kaufmann (2000) and Hellman and Schankerman (2000). 
Figure 2: The agent's dilemma: Strip assets or build value

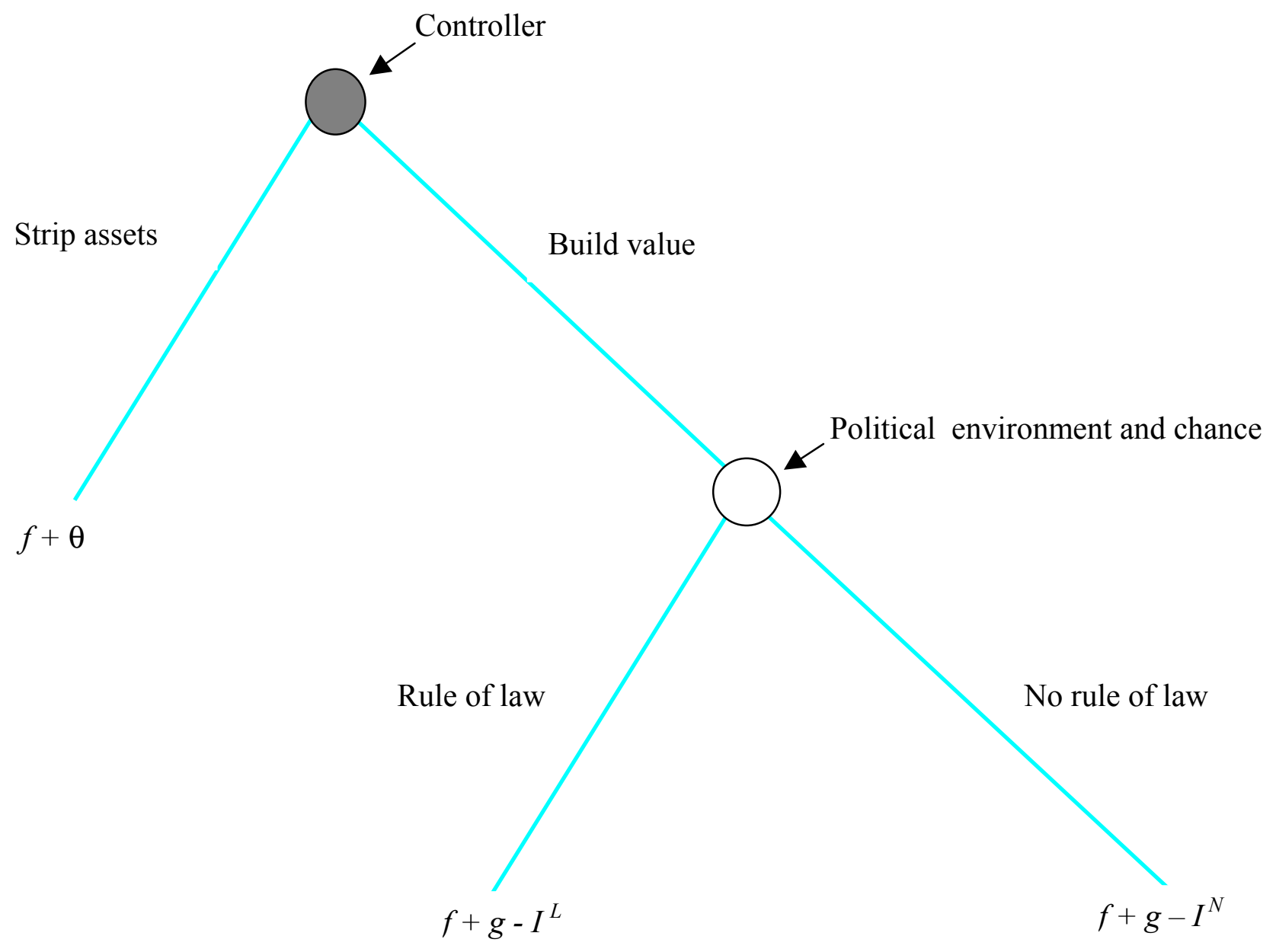


Figure 3. Static model: Multiple equilibria

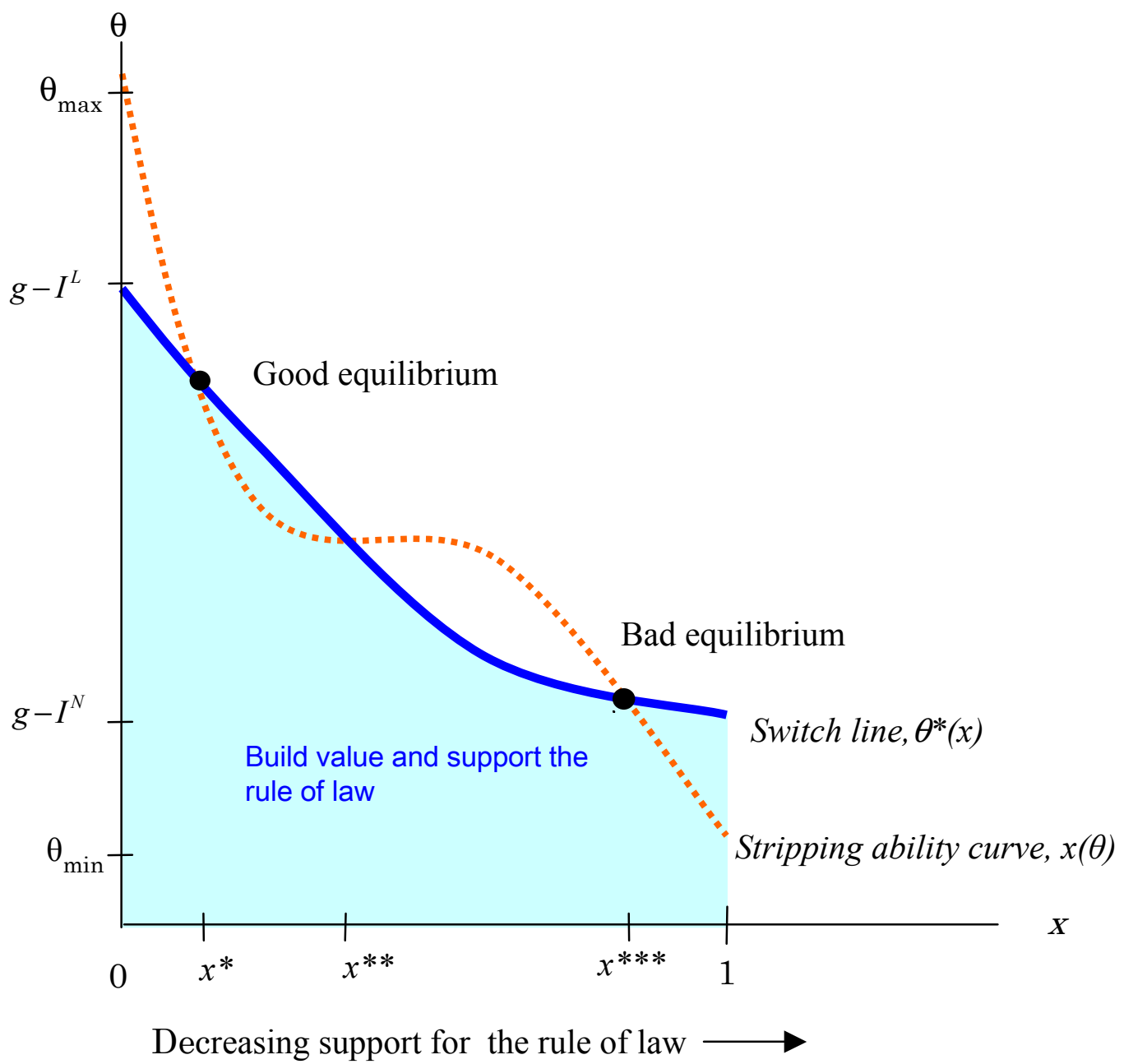


Figure 4. Numerical example

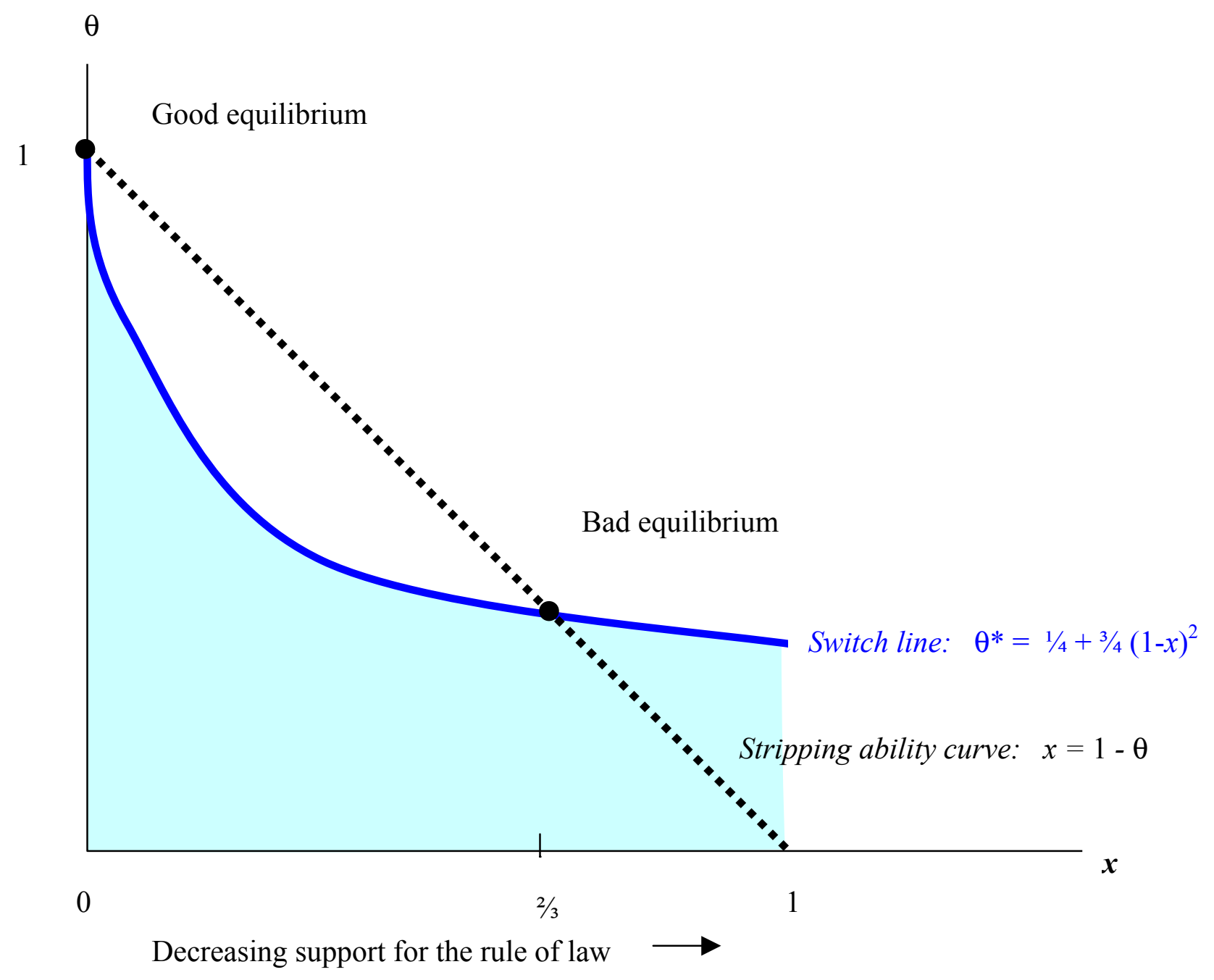


Figure 5. Comparative statics: (A) A shift up in the stripping ability curve. (B) A shift down in the switch line.
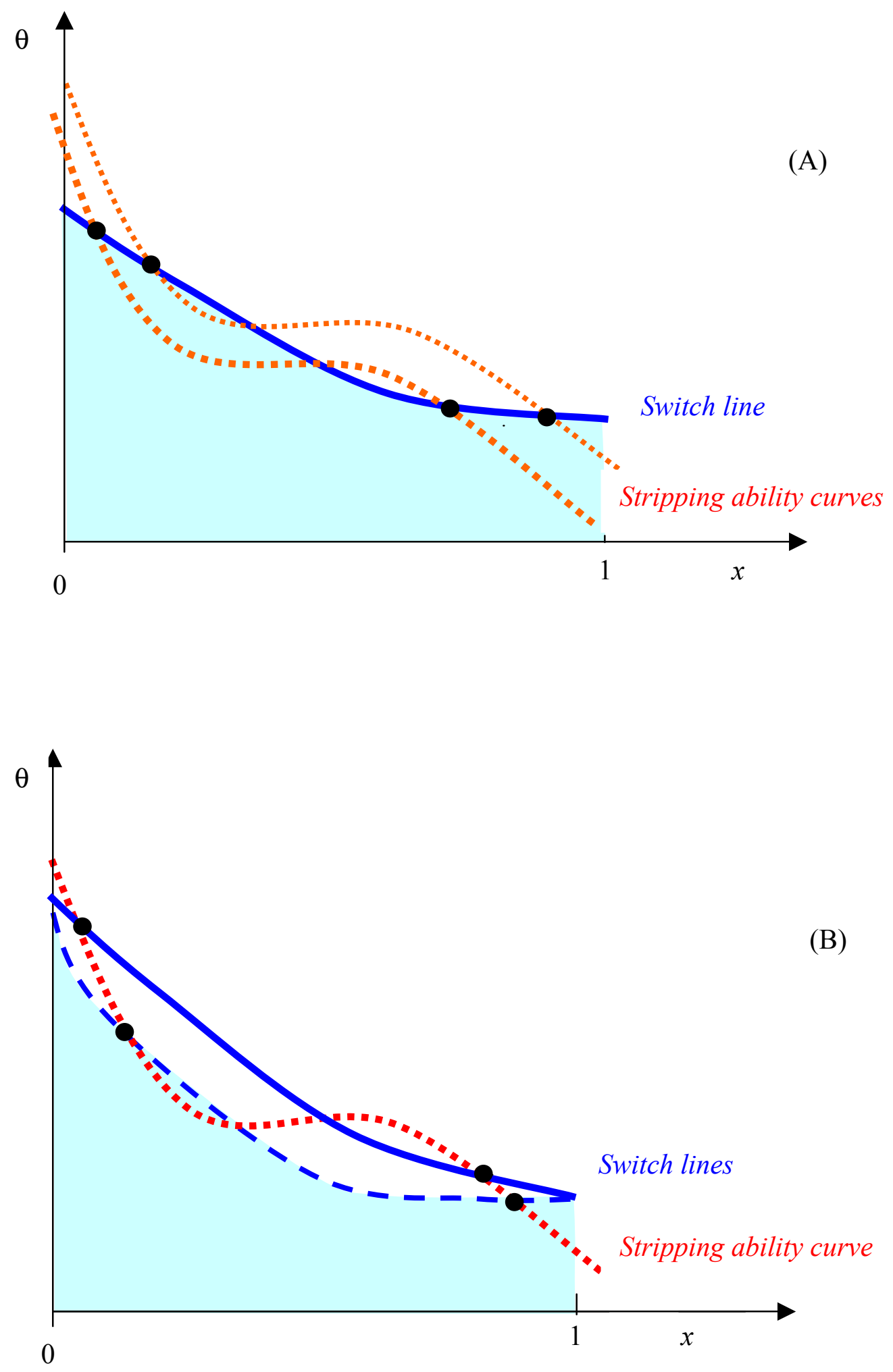
Table 1. Natural resource abundance, growth, and property rights insecurity

\begin{tabular}{|c|c|c|c|c|c|c|}
\hline \multirow[t]{2}{*}{ Country } & \multicolumn{3}{|c|}{$\begin{array}{l}\text { Measures of Natural } \\
\text { Resource Abundance }\end{array}$} & \multicolumn{3}{|c|}{ Performance Measures } \\
\hline & $\begin{array}{l}\text { Fuel and } \\
\text { mineral } \\
\text { exports/ } \\
\text { total exports } \\
\text { (percent) }\end{array}$ & $\begin{array}{l}\text { Fuel and } \\
\text { mineral } \\
\text { exports/ } \\
\text { GDP } \\
\text { (percent) }\end{array}$ & Year & $\begin{array}{l}2000 \\
\text { GDP/ } \\
1989 \\
\text { GDP } \\
\text { (percent) }\end{array}$ & $\begin{array}{l}\text { \% believe legal } \\
\text { system will not } \\
\text { "uphold my } \\
\text { contract and } \\
\text { property rights in } \\
\text { business } \\
\text { disputes" } \\
\text { (EBRD/WB } \\
\text { survey) }\end{array}$ & $\begin{array}{l}\text { Wall Street } \\
\text { Journal } \\
\text { rule of law } \\
\text { index } \\
(10=\text { best, } \\
0=\text { worst })\end{array}$ \\
\hline Moldova & 3.80 & 0.69 & 1994 & 33 & 74 & 4.7 \\
\hline Slovenia & 4.36 & 1.65 & 1994 & 114 & 26 & 8.4 \\
\hline Hungary & 7.00 & 1.70 & 1994 & 104 & 29 & 8.7 \\
\hline $\begin{array}{l}\text { Slovak } \\
\text { Republic }\end{array}$ & 8.04 & 3.13 & 1994 & 103 & 36 & 6.4 \\
\hline $\begin{array}{l}\text { Czech } \\
\text { Republic }\end{array}$ & 8.48 & 2.43 & 1994 & 98 & 55 & 8.3 \\
\hline Estonia & 9.18 & 3.68 & 1995 & 83 & 23 & 8.5 \\
\hline Average & 6.81 & 2.21 & & 89 & 40 & 7.5 \\
\hline Croatia & 11.02 & 3.16 & 1994 & 80 & 34 & 7.0 \\
\hline Romania & 13.63 & 2.81 & 1994 & 77 & 43 & 5.6 \\
\hline Bulgaria & 16.17 & 6.72 & 1996 & 71 & 43 & 5.9 \\
\hline Poland & 16.98 & 2.82 & 1994 & 127 & 25 & 8.7 \\
\hline Lithuania & 18.32 & 5.96 & 1994 & 65 & 65 & 7.2 \\
\hline Average & 15.22 & 4.29 & & 84 & 42 & 6.9 \\
\hline $\begin{array}{l}\text { Kyrgyz } \\
\text { Republic }\end{array}$ & 23.63 & 2.93 & 1995 & 66 & 71 & 4.4 \\
\hline Kazakhstan & 48.86 & 12.87 & 1995 & 69 & 59 & 4.5 \\
\hline Russia & 53.16 & 14.44 & 1996 & 63 & 73 & 3.7 \\
\hline Average & 41.88 & 10.08 & & 66 & 68 & 4.2 \\
\hline
\end{tabular}

Note: Countries are listed in increasing order of natural resource abundance, as measured in column 2.

Source: Rule of law ratings are from the Central European Economic Review, a supplement to the Wall Street Journal. Export and GDP data for columns 2 and 3 are from Statistical Information and Management Analysis (SIMA), World Bank. Growth data in column 5 are from EBRD 2001. 
Figure 6. Dynamic model: (A) An agent's action and support for the rule of law, as a function of his type and the political environment. (B) Multiple equilibria.

(A)

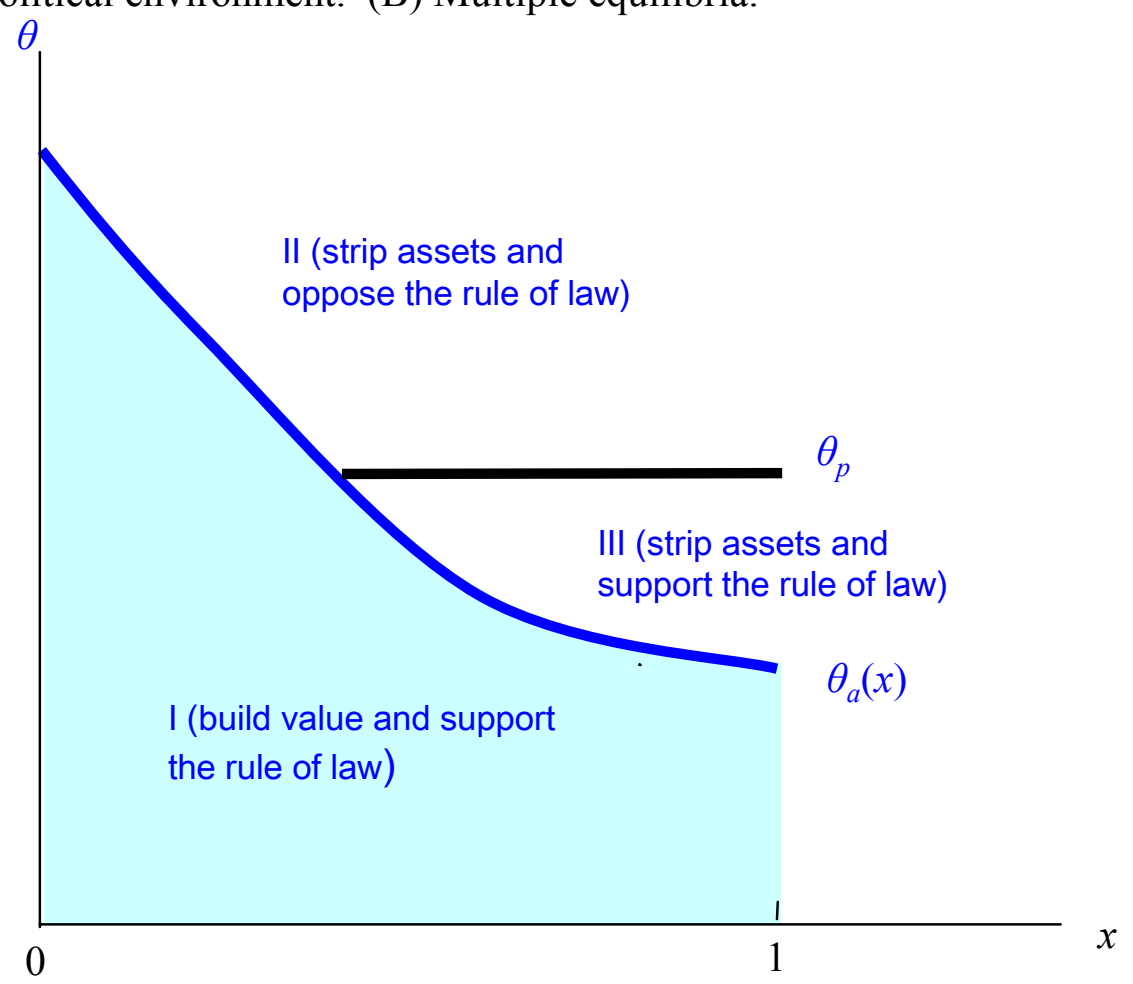

(B)

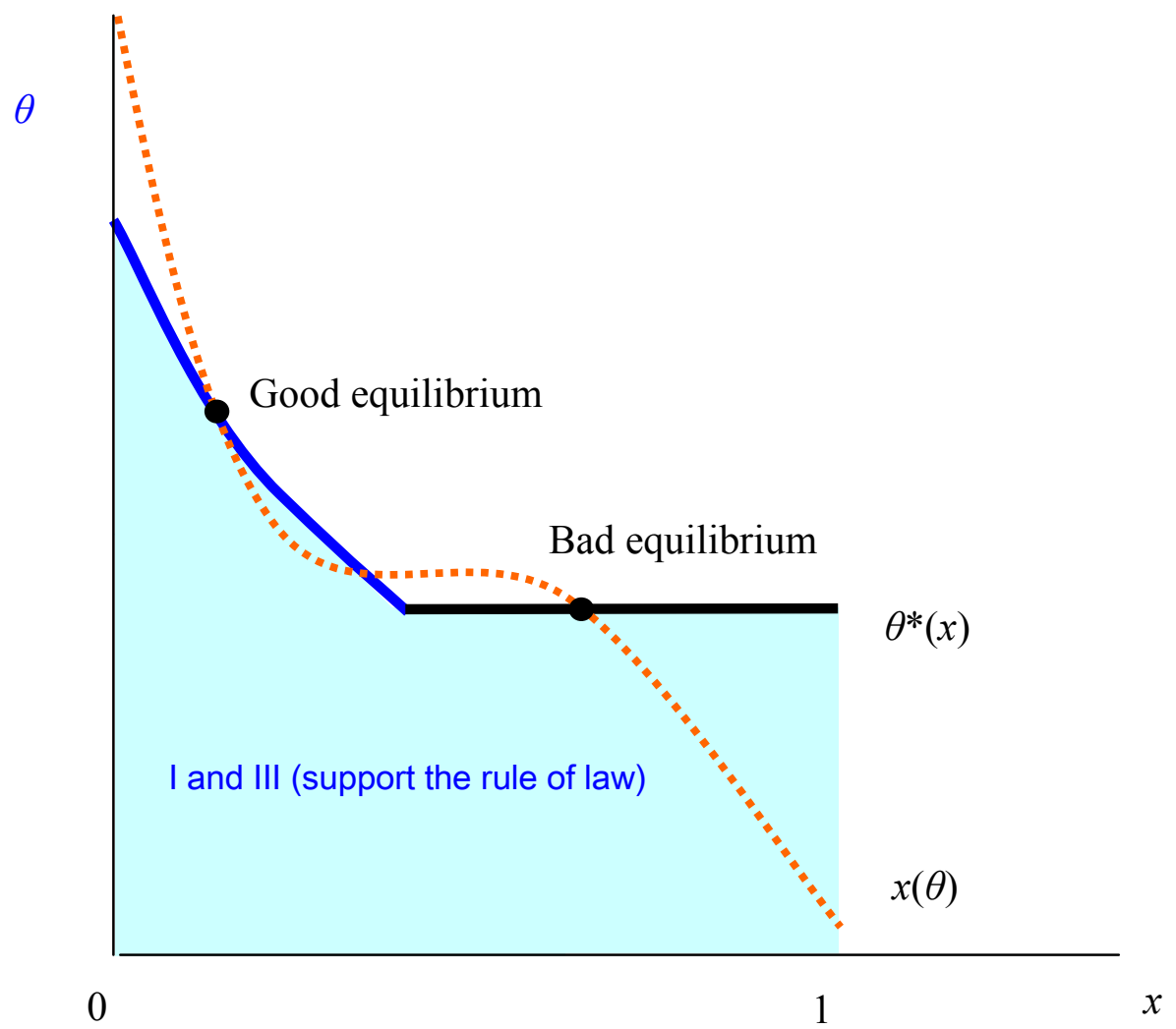


Figure 7. Time path of expected GDP

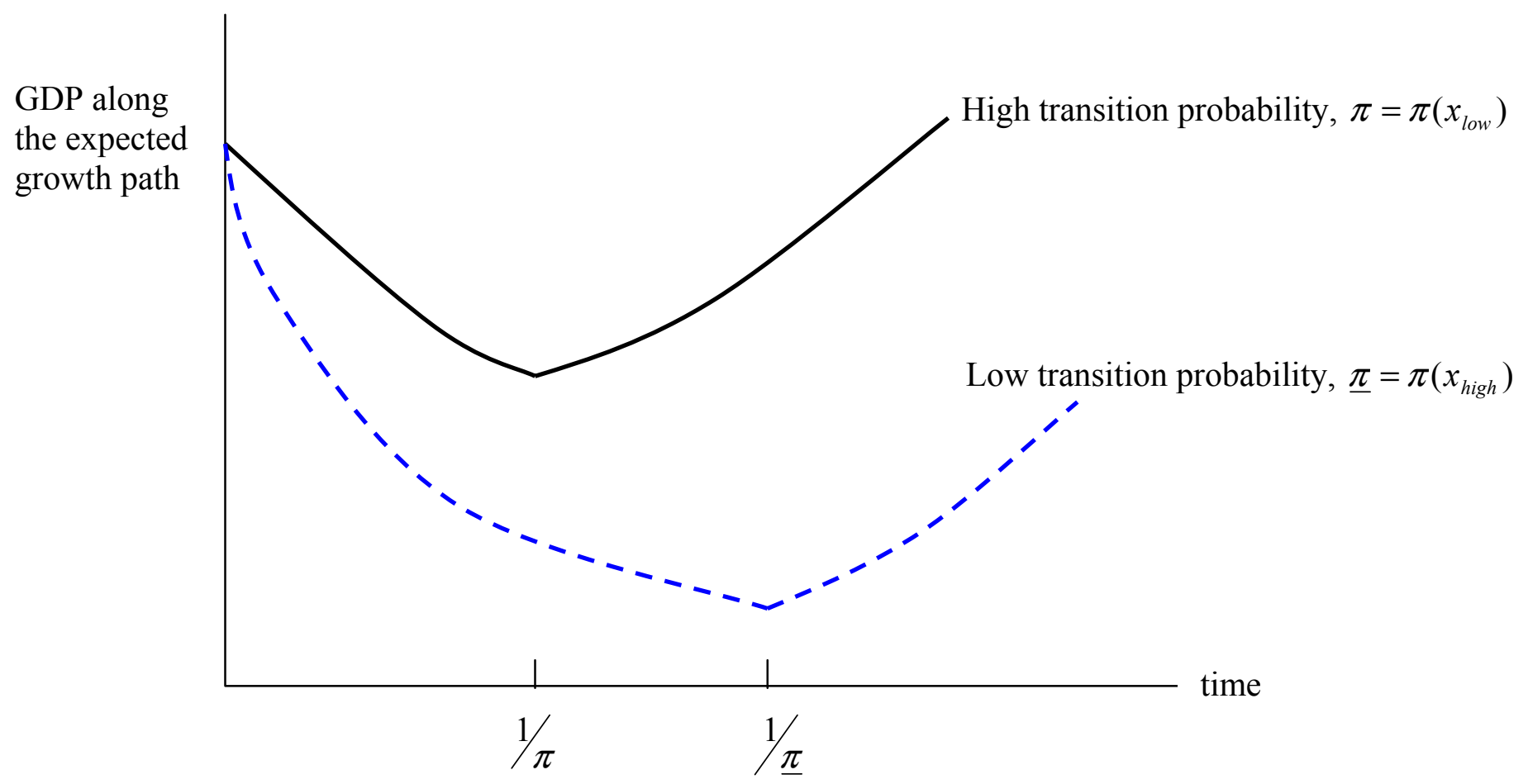


Figure 8. Rule-of-law constraint

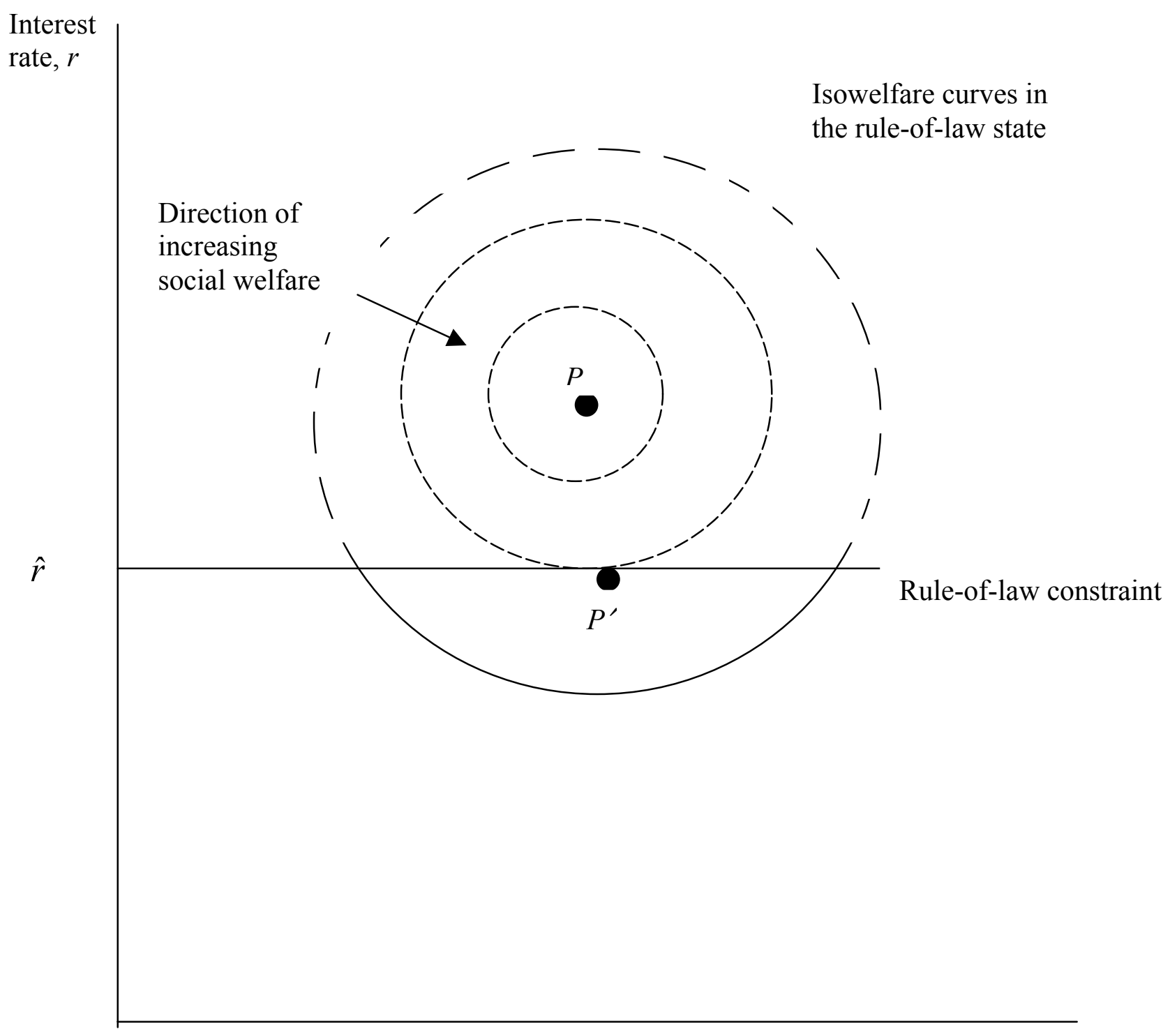

Government spending, $G$ 